Check for updates

Cite this: RSC Adv., 2019, 9, 34926

\title{
Facile green synthesis and applications of silver nanoparticles: a state-of-the-art review
}

\author{
Nazia Tarannum, (D)*a Divya (D) a and Yogendra K. Gautam (D) b
}

In the field of nanotechnology, the development of reliable and eco-friendly methods for the synthesis of NPs is crucial. The conventional methods for the synthesis of NPs are costly, toxic, and not ecofriendly. To overcome these issues, natural sources such as plant, bacteria, fungi, and biopolymers have been used to synthesize AgNPs. These natural sources act as reducing and capping agents. The shape, size, and applications of AgNPs are prominently affected by the reaction parameters under which they are synthesized. Accessible distributed data on the synthesis of AgNPs include the impact of different parameters (temperature and $\mathrm{pH}$ ), characterization techniques (DLS, UV-vis, FTIR, XRD, SEM, TEM and EDX), properties and their applications. This review paper discusses all the natural sources such as plants, bacteria, fungi, and biopolymers that have been used for the synthesis of AgNPs in the last ten years. AgNPs synthesized by green methods have found potential applications in a wide spectrum of areas including drug delivery, DNA analysis and gene therapy, cancer treatment, antimicrobial agents, biosensors, catalysis, SERS and magnetic resonance imaging (MRI). The current limitations and future prospects for the synthesis of inorganic nanoparticles by green methods are also discussed herein.

Received 2nd June 2019

Accepted 7th October 2019

DOI: $10.1039 / \mathrm{c} 9 \mathrm{ra0} 4164 \mathrm{~h}$

rsc.li/rsc-advances
Around 5000 years back, numerous Egyptians, Persians, Greeks and Romans utilized silver in several structures to store nourishment items. ${ }^{4}$ During ancient periods, silverware was used in household daily activity due to its antimicrobial activity. There are records regarding the therapeutic applications of silver in the literature as early as $300 \mathrm{BC}$. Until the revelation of antimicrobials by Alexander Flemming, silver was ordinarily utilized as an antimicrobial specialist. In the Hindu religion, to date, silverware is favored for making the "panchamrit" utilizing Ocimum sanctum, curd, and different ingredients. The restorative properties of different metals are referenced in the old Indian Ayurvedic prescription book named "Charak Samhita".

In the past, AgNPs have attracted considerable attention from analysts. Due to the uncommon attributes of AgNPs, they are used in different fields such as biomedical (fast diagnosis, imaging, tissue regeneration and drug delivery, and development of new medical products),${ }^{7}$ textile industry, ${ }^{8}$ food packaging, ${ }^{9}$ cosmetic industry, ${ }^{10}$ catalysis, ${ }^{\mathbf{1 1}}$ sensors, ${ }^{\mathbf{1 2}}$ biology, coatings, ${ }^{13}$ plasmonics (SERS), ${ }^{14}$ optoelectronics, ${ }^{15}$ antimicrobial activities, ${ }^{16}$ DNA sequencing, ${ }^{17}$ SERS, ${ }^{18}$ climate change and contamination control, ${ }^{19}$ clean water technology, ${ }^{20}$ energy generation, and information storage. Also, due to their remarkable protection against a wide scope of microorganisms and medicinal properties, AgNPs are utilized as anti-infection agents, tranquilizers conveyance agents, water treatment, farming, etc. ${ }^{21}$ Furthermore, due to their high conductivity, AgNPs have found application in electronic devices, inks, adhesives, pastes, etc. ${ }^{22}$ Generally, the synthesis of AgNPs is
${ }^{a}$ Department of Chemistry, Chaudhar
India.E-mail: naz1012@gmail.com

${ }^{b}$ Smart Materials and Sensor Laboratory, Department of Physics, Chaudhary Charan Singh University, Meerut 250004, India 
carried out using physiochemical techniques such as autoclaving, gamma-ray radiation, use of microemulsions, electrochemical techniques, chemical reduction, laser ablation, microwave irradiation, and photochemical reduction. ${ }^{23-33}$ Fig. 1 presents the various techniques used for the synthesis of NPs.

The above methods have a high yield, but simultaneously they have limitations such as the use of toxic chemicals, and high functional cost and energy requirement. To overcome the limitations of physiochemical methods, alternative costeffective methods involving plant extracts, microorganisms and natural polymers have been used for the synthesis of AgNPs. The combination of green chemistry and nanotechnology has extended the range of cytogenetically and biologically compatible metallic NPs. ${ }^{4}$

Over the previous decade, few review concentrating on the green synthesis of AgNPs have been published. ${ }^{34}$ The majority of them concentrated on a few plants (aloe leaf, ${ }^{35}$ cherry extract, ${ }^{36}$ Coffea arabica seed, ${ }^{37}$ Trianthema decandra, ${ }^{38}$ Macrotyloma uniflorum, $^{39}$ and Rosa rugosa ${ }^{40}$ ), biopolymers ${ }^{41}$ (chitosan $^{42,43}$ ) and microbial sources ${ }^{44}$ for the synthesis of AgNPs. Several characterization procedures (DLS, UV-vis, FTIR, XRD, SEM, TEM and EDX) have been employed to investigate information regarding the source, shape, size and properties of AgNPs with respect to different applications. The present review, in contrast to the prior reviews, focuses on the synthetic methods, parameters, characterization techniques, applications, and anticipated antibacterial components from different green ways for the synthesis of AgNPs.

\section{Green synthesis}

The basic requirement for the green synthesis of AgNPs is silver nitrate and a natural reducing agent. ${ }^{\mathbf{1 0}-30}$ Generally, a natural reducing agent or different components present in the cell work as stabilizing or capping agents, and thereby the need to include these agents from outside is minimized. ${ }^{4}$ The traditional strategies for the production of NPs are costly, harmful, not environment-friendly. Thus, to overcome these issues, specialists have adopted green methods for the synthesis of NPs. ${ }^{45}$ Natural resources and their constituents have been utilized to synthesize NPs. Green synthesis can be classified as: (a) from plants and their extracts, (b) from bacteria, (c) from fungi and (d) from biopolymers. Various reducing agents have been used for the synthesis of AgNPs, which are shown in Table 1 with the general mechanism for the synthesis of AgNPs. The green synthesis via plants and plant extracts, bacteria, fungi, and biopolymers is described in the next sections of this review.

\subsection{Synthesis of AgNPs from plants}

The plant-based synthesis of AgNPs is generally adopted more compared to methods that use microorganisms since it can be improved easily, less bio-threatening and do not include the step of cell culture growth. ${ }^{\mathbf{4 6 - 5 0}}$ All the parts of a plant (leaves, fruits, roots, seeds, and stems) contain biomolecules (e.g. enzymes, alkaloids, polysaccharides, tannins, terpenoids, phenols, and vitamins), which are of great therapeutic value and, despite their complex structures, are good for the

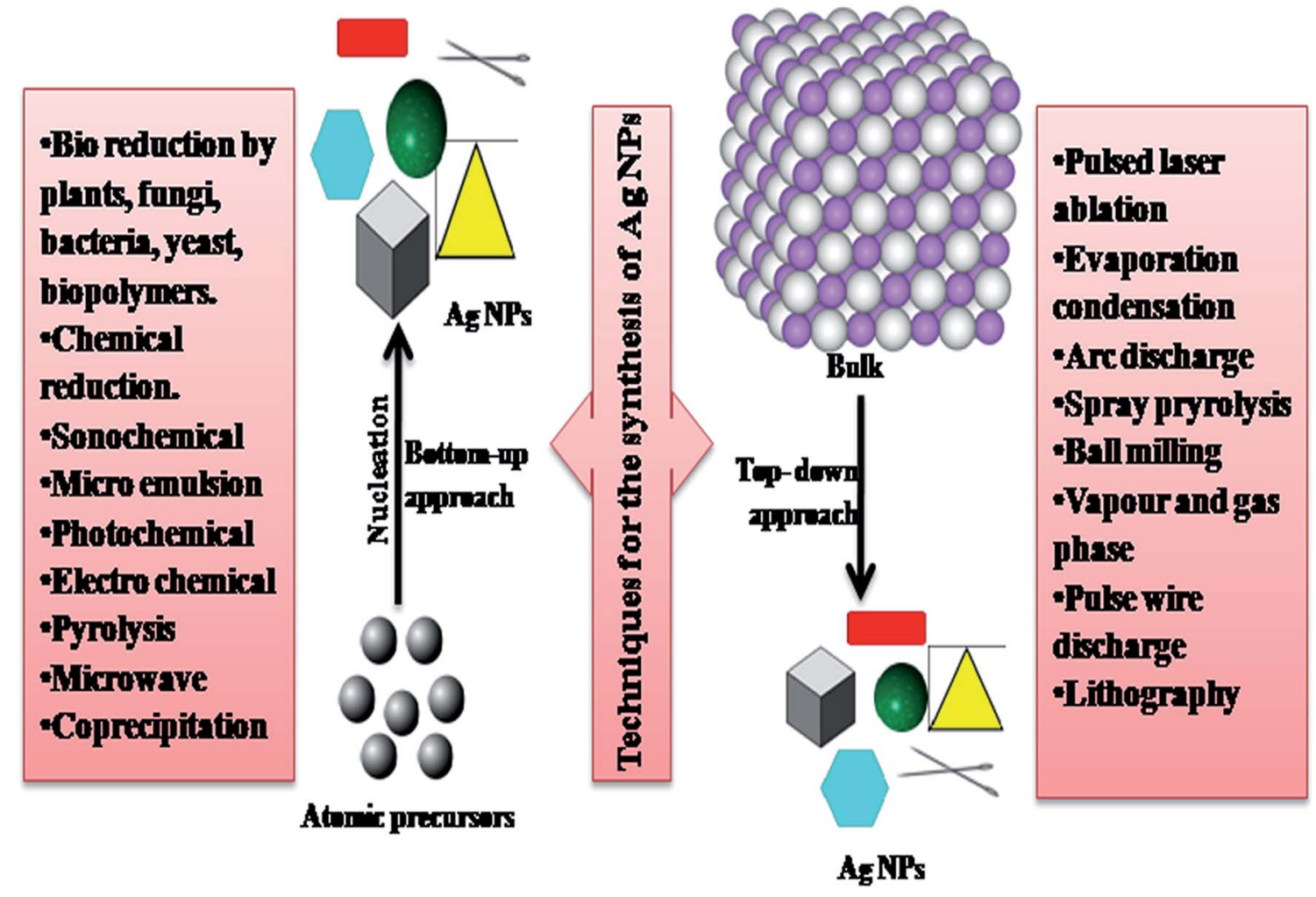

Fig. 1 Representation of various techniques for the synthesis of NPs. ${ }^{6}$ 
Table 1 Various constituents of plant, bacteria, fungi, and biopolymer responsible for the reduction of silver nitrate to AgNPs

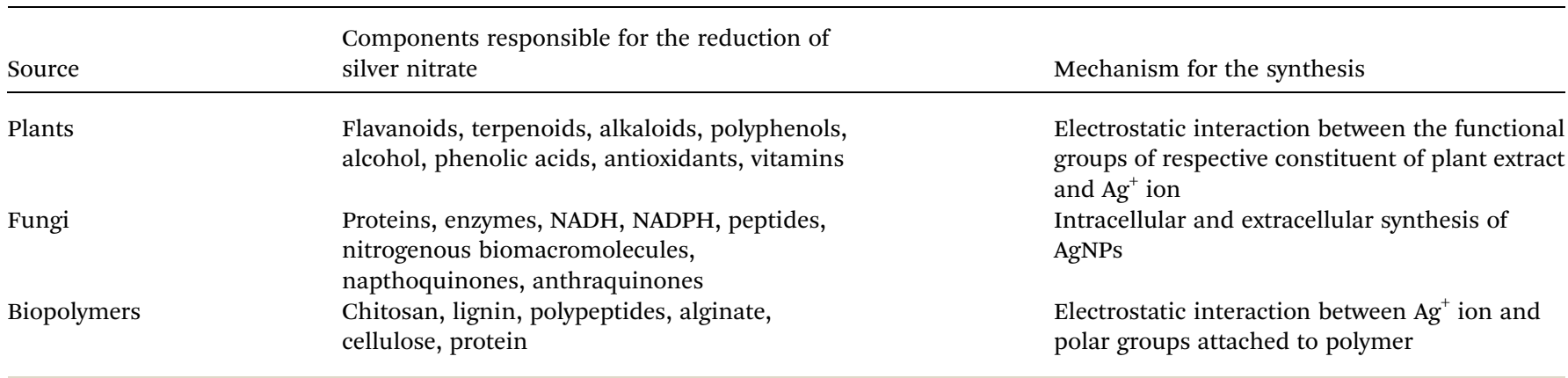

environment. ${ }^{51}$ Plant extract replaces all toxic chemicals such as trisodium citrate and sodium borohydride $\left(\mathrm{NaBH}_{4}\right)$. The extract from plants assists well in the synthesis of NPs due to the formation of AgNPs stabilized by the flavonoid and terpenoid components present in leaf broth, while the reduction of silver ions is favored by the polyol and water-soluble heterocyclic components of leaf broth. ${ }^{52}$ The extract of plant Salvia spinosa grown under in vitro conditions was used for the first time to synthesize AgNPs. ${ }^{53}$ The first report on the formation of AgNPs by a living plant system Alfalfa sprouts was presented by Gardea Torresdey et al. (2003). Alfalfa roots can absorb Ag from agar medium and transfer them in the same oxidation state to the shoots of the plant. These Ag atoms are converted to AgNPs in the shoots. ${ }^{54}$ Harekrishna Bar et al. (2009) reported the use of the latex of Jatropha curcas as the reducing and capping agent to synthesize AgNPs. ${ }^{55}$ Sithara et al. synthesiszed AgNPs by using leaf extract of Acalypha hispida and these AgNPs were used for the detection of $\mathrm{Mn}^{2+}$ ions. ${ }^{56}$ Gavhane et al. (2012) reported the use of the extract of Neem and Triphala to synthesize AgNPs, which were characterized using EDX, TEM, and NTA. TEM and NTA revealed the size of the AgNPs was in the range of $43 \mathrm{~nm}$ to $59 \mathrm{~nm}$ and they were spherical in shape. ${ }^{57}$ Ahmad and Sharma (2012) utilized (pineapple juice) Ananas comosus as a stabilizing and reducing agent for the synthesis of AgNPs. ${ }^{58}$ Charusheela Ramteke et al. (2012) synthesized antibacterial AgNPs using the leaf extract of (Tulsi) Ocimum sanctum..$^{59}$ Roy et al. (2014) used Malus domestica fruit extract as a reducing and capping agent to synthesize AgNPs with an average diameter of $20 \mathrm{~nm}$. The formation of the NPs was characterized by UV-vis spectroscopy, their morphology and distinctive phases were analyzed by TEM and XRD, and biomolecules for the reduction and stabilization of NPs were identified via FTIR spectroscopy. ${ }^{60}$ Velmurugan et al. (2015) synthesized AgNPs using peanut shell extract and compared their antifungal activity and characteristics with that of commercial AgNPs. ${ }^{\mathbf{6 1}}$

Prem Jose Vazhacharickal et al. (2015) synthesized AgNPs using Curry leaf (Murraya koenigii) as the reducing and capping agent, which exhibited good antibacterial activity. ${ }^{62}$ M. Firdaus et al. (2017) reported the synthesis of AgNPs using aqueous fruit extract from (Carica papaya) papaya as the reductant under sunlight irradiation without additional capping agents. The AgNPs were characterized via UV-vis spectrophotometry and FTIR spectroscopy. A green environmental sensor was developed due to the good selectivity of
AgNPs towards the hazardous heavy metal mercury in aqueous solution. ${ }^{63}$ Jerushka S. Moodley et al. (2018) reported the antimicrobial potential of synthesized AgNPs using leaf extracts of Moringa oleifera and utilized sunlight irradiation as the primary source of energy. ${ }^{64}$ Yu C. et al. (2019) synthesized AgNPs from the leaf extract of Eriobotrya japonica (Thunb) and utilized them in the catalytic degradation of reactive dyes. ${ }^{65}$ The most suitable choice to synthesize AgNPs is plant-like angiosperms. Medicinally important plants such as Boerhaaviadiffusa, ${ }^{66}$ Tinosporacordifolia, ${ }^{67}$ Terminalia chebula, ${ }^{68}$ aloe vera $^{69}$, Ocimumtenuiflorum, ${ }^{70}$ Catharanthus roseus, ${ }^{71}$ Emblica officinalis ${ }^{72}$, Azadirachtaindica ${ }^{73}$ common spices Piper nigrum, ${ }^{74}$ Cocos nucifera ${ }^{75}$, Cinnamon zeylanicum ${ }^{76}$ and some tropical weeds such as Partheniumhystero-phorus ${ }^{77}$ have been utilized to synthesize AgNPs. Plants that produce essential oils (Mentha piperita) and alkaloids (Papaver somniferum) have also been used to synthesize AgNPs. The have been a few cases in which chemicals such as sodium-dodecyl sulfate were used externally to stabilize AgNPs. ${ }^{78}$ All the plant extracts act as both reducing agents and capping agents. The proteins metabolites ${ }^{79}$ and chlorophyll ${ }^{80}$ present in the extract of plants act as stabilizing agents to synthesize AgNPs. Fig. 2 presents the mechanism for the synthesis of AgNPs from plants. Other synthetic procedures, conditions, characterization and application of AgNPs are discussed below (Table 2).

\subsection{Green synthesis of AgNPs from bacteria}

NPs of noble metals such as Ag and Gold have been synthesized utilizing either intra or extracellular inorganic materials created by bacteria. ${ }^{130}$ Fig. 3 shows the synthetic procedure for the synthesis of AgNPs from the biomass of bacteria. Slawson et al. (1992) reported that AgNPs are biocompatible in a few bacteria, which are Ag-resistant. ${ }^{131}$ Pooley (1982) reported that bacteria aggregate $\mathrm{Ag}$ on the bacterial cell walls, and recommended the use of bacteria to industrially recover $\mathrm{Ag}$ from ore. ${ }^{132}$ First, Klaus et al. (1999) synthesized AgNPs using the biomass of the Pseudomonas stutzeri AG259 bacteria (Ag resistant). The amount of AgNPs accumulated by the bacteria cells was up to $200 \mathrm{~nm} .^{\mathbf{1 3 3}}$ Kalimuthu et al. (2008) reported the synthesis of AgNPs with a size of $50 \mathrm{~nm}$ by adding silver nitrate aqueous solution to the biomass of $B$. licheniformis. A whitish-yellow to brown color confirmed the formation of AgNPs stabilized by the nitrate of enzymes. ${ }^{134}$ Nanda and Saravanan (2009) also synthesized AgNPs utilizing culture supernatants of Staphylococcus aureus. 


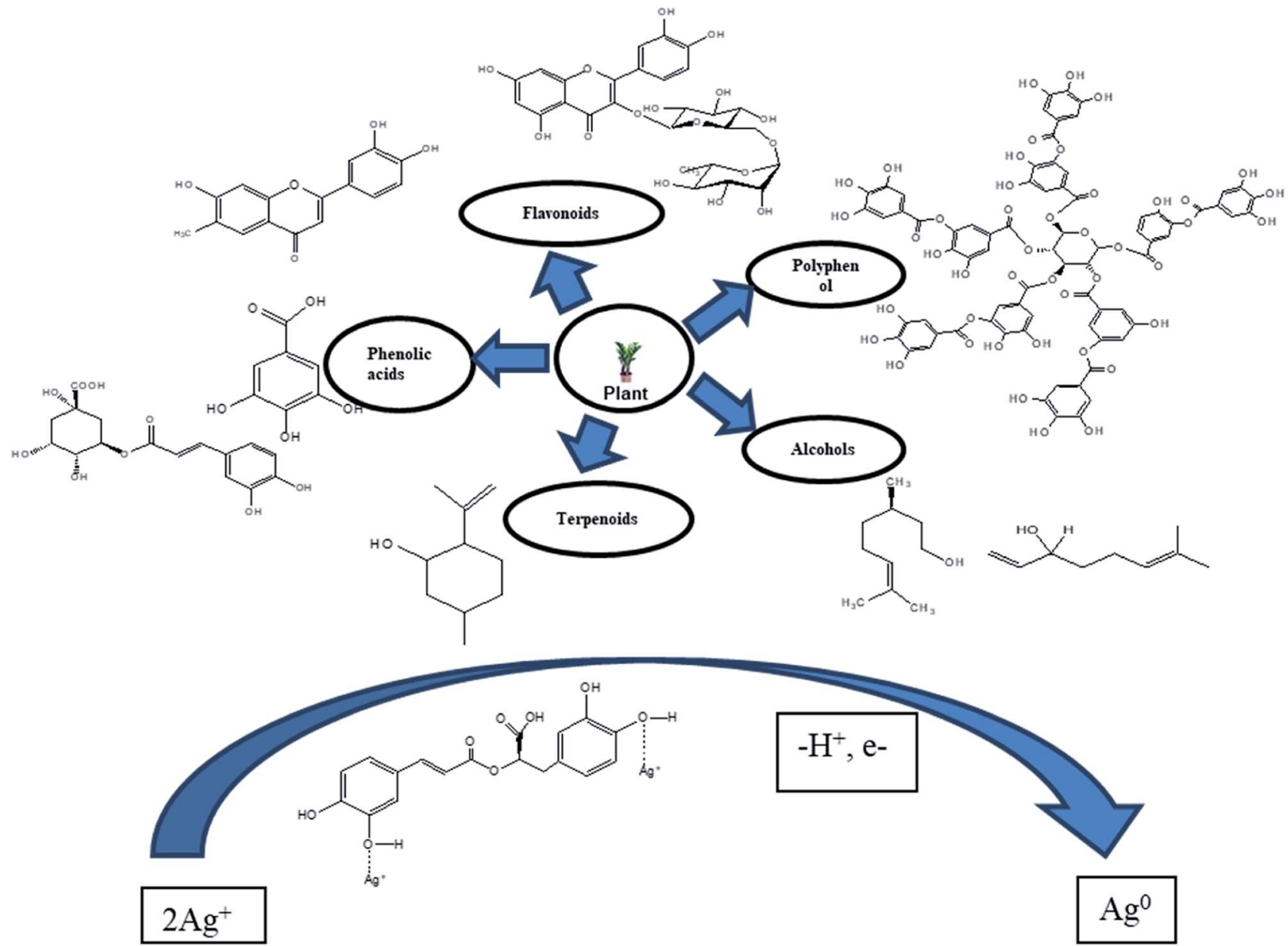

Fig. 2 Mechanism for the synthesis of AgNPs from plant sources.

However, the culture supernatants from Enterobacteriaceae can be used for the quick synthesis of AgNPs. ${ }^{135}$ Shivaji et al. (2011) synthesized AgNPs utilizing culture supernatants of psychrophilic bacteria. ${ }^{136}$ Monowar et al. (2018) reported the extracellular synthesis of AgNPs utilizing the extract of an endophytic bacterium from Pantoeaananatis. ${ }^{137}$ Samadi et al. (2009) reported the use of Proteus mirabilis PTCC 1710 bacteria to synthesize AgNPs. During the incubation of bacteria, different types of broth are used for advancement in extracellular and intracellular synthesis. The mechanism for the green synthesis of AgNPs from bacteria is shown Fig. 3 .

The choice of bacteria in the green synthesis of AgNPs and an appropriate method are important for their large scale production. ${ }^{138}$ Mokhtari et al. (2009) reported the synthesis of AgNPs via photosynthesis by adding a solution of silver nitrate to the culture supernatant of Klebsiella pneumonia, and showed visible-light irradiation prompted the synthesis of AgNPs with a size of $3 \mathrm{~nm}^{139}$. According to reports by Lee and Shehata and Marr (Lee 1996; Shehata and Marr 1971), AgNPs were also produced via the reduction of silver ions using culture supernatants of bacteria. It should be noted that the growth of bacteria depends on the nutrients in the culture medium (glucose, phosphate or tryptophan). ${ }^{140}$ Shahverdi et al. (2007) reported the use of Enterobacter cloacae (Enterobacteriaceae), Escherichia coli and Klebsiella pneumonia for the fast synthesis of AgNPs, which formed AgNPs within a few minutes of $\mathrm{Ag}$ ions reacting with the cell filtrate. ${ }^{141}$ Kharissova et al. (2013) highlighted that bacteria kept on growing after the synthesis of AgNPs. However, compared to conventional methods, the utilization of bacteria for the reduction of $\mathrm{Ag}^{+}$ions leads to a slow formation rate and limited range of shapes and sizes of AgNPs. ${ }^{142}$ Therefore, fungi-based NPs and reducing agents involving plants and plant extracts have been investigated for the synthesis of AgNPs (Table 3).

\subsection{Synthesis of AgNPs from fungi and yeast}

Organic matter provides unique traits for the synthesis of NPs with advanced properties. Fungi are the main choice of microorganisms for the synthesis of NPs due to their vast range of advantages over yeast, bacteria, plants, and physicochemical techniques. ${ }^{144}$ Fig. 4 presents the mechanism for the synthesis of AgNPs using fungi.

Fungi can synthesize metal NPs since they secrete enzymes and proteins, which are used to reduce metal salts. The largescale synthesis of NPs from distinct fungal strains has been implied due to their growth even in vitro ${ }^{145}$. Xue B. et al. (2016) 
Table 2 Synthesis using plant extracts generates NPs with well-defined shapes, structures, and morphologies compared to that obtained using the bark, tissue, and entire plant

S. Reducing agents (green no. sources)

Applications

Operating conditions

Characterization

techniques used

$\mathrm{AgNO}_{3}(1 \mathrm{mM})$, extract: UV-vis, FTIR, TEM,

$\mathrm{AgNO}_{3}(1: 10)$, stir

$20 \mathrm{~min}$, incubated for 24

$\mathrm{h}$

2 Cherry extract

Antioxidant

$\mathrm{AgNO}_{3}(1 \mathrm{mM})$, extract:

$\mathrm{AgNO}_{3}(1: 10)$

Antibacterial activity on

E. coli and S. aureus

$\mathrm{AgNO}_{3}(0.02 \mathrm{M}, 0.05 \mathrm{M}$ and $0.1 \mathrm{M})$, volume of extract kept constant for each solution

4 Plant extract of Trianthema decandra

Antimicrobial activity

$\mathrm{AgNO}_{3}(1 \mathrm{mM})$, extract: $\mathrm{AgNO}_{3}(1: 5,1: 10$, $1: 15$ )

$\mathrm{AgNO}_{3}(0.59 \mathrm{mM})$, extract: $\mathrm{AgNO}_{3}(1: 60)$

$\mathrm{AgNO}_{3}(1 \mathrm{mM})$, extract: $\mathrm{AgNO}_{3}(1.8: 50)$

6 Fruit extract of Tanacetum vulgare

7 Leaf extracts of Rosa rugosa

8 Saccharum officinarum

High antimicrobial activity against biofilmforming bacteria and $\mathrm{AgNO}_{3}(1 \mathrm{mM})$, extract: $\mathrm{AgNO}_{3}(2.5: 60)$

$\mathrm{AgNO}_{3}(14,24,52$, and $104 \mathrm{mM}$ ),

fungi. Reduce cytotoxicity $(5: 1: 1)$, stirred for 12 on mammalian somatic $15 \mathrm{~h}$ with heat and tumoral cells

9 Seed extract of Nelumbo nucifera

10 Eriobotrya japonica (Thunb.) leaf extract

11 Sapota pomace extract (Manilkara zapota)

Antibacterial and antifungal

$\mathrm{AgNO}_{3}(1 \mathrm{mM})$, seed Catalytic degradation of reactive dyes

Good antibacterial activity against Grampositive and Gramnegative bacteria

12 Pomegranate peel extract Antibacterial activity (Punica granatum)

against Staphylococcus, Pseudomonas aeruginosa and Escherichia coli pathogens

13 Saccharum officinarum extract and chitosan

14 Arbutus unedo (strawberry) leaf extract

Antibacterial against planticola, Streptococcus at $37^{\circ} \mathrm{C}$, till change in faecalis, Pseudomonas aeruginosa and Escherichia coli Cost effectiveness, medical and pharmaceutical applications extract: $\mathrm{AgNO}_{3}(1: 19)$
Different ratios of leaf extract and silver salt solution $(1: 1,1: 2$, and $1: 10, \mathrm{v} / \mathrm{v})$

$\mathrm{AgNO}_{3}(7 \mathrm{mM})$, mixed with extract in ratio $1: 0.5(\mathrm{v} / \mathrm{v})$, temperature $20{ }^{\circ} \mathrm{C}$

$\mathrm{AgNO}_{3}$ (1 mM), mixed with extract (incubated for $24 \mathrm{~h}$ ) applications

15 Pomegranate leaf extract activity on human cervical cancer cells ${ }^{86}$

16 Walnut seed extract

17 Cinnamomum camphora

leaf extract
Used in photocatalytic degradation of effluent dye

\author{
.
}


Table 2 (Contd.)

S. Reducing agents (green no. sources)

18 Pomegranate peel extract Photocatalytic degradation of methylene temperature: $\left(21 \pm 5{ }^{\circ} \mathrm{C}\right)$ blue

19 Azadirachta indica aqueous leaf extract

Antibacterial activity against Staphylococcus aureus and Escherichia coli

20 Grape (Vitis vinifera) fruit Antibacterial activity extract against Bacillus subtilis and Escherichia coli

21 Alpinia katsumadai seed extract

22 Apple extract antibacterial and antioxidant Antibacterial against Gram-negative and Gram-positive bacteria with MIC of $125 \mathrm{mg} \mathrm{mL}^{-1}$

23 Berberis vulgaris leaf and Antibacterial activity root extract against Escherichia coli and Staphylococcus bacteria

24 Cinnamon zeylanicum bark extract and powder

$\mathrm{AgNO}_{3}(1 \mathrm{mM}$ to $5 \mathrm{mM})$ added to $10 \mathrm{~mL}$ of $\mathrm{AgNO}_{3}$ solution $\mathrm{AgNO}_{3}$ solution (1:1) stir: $200 \mathrm{rpm}$ for $90 \mathrm{~min}$ $\mathrm{AgNO}_{3}(0.1 \mathrm{M})$ extract: $\mathrm{AgNO}_{3}(1: 9)$ stir and

heat at $80^{\circ} \mathrm{C}$ extract: $(3,5,10,15,30$ $\mathrm{mL})$ contact time: $(1,2,6$, $12,24 \mathrm{~h}$ )
25 Lippia nodiflora aerial extract
Antioxidant and antibacterial against human pathogenic bacteria, cytotoxic against MCF-7 breast cancer cell lines

26 Andean blackberry fruit Antioxidant extract

27 Aqueous broccoli extract High toxicity against MCF-7 cell line

28 Pinus merkusii cone flower extract

29 Curcuma longa tuber (turmeric) powder and extract

Immobilization on cotton cloth for bactericidal activity
30 Garlic extract (Allium sativum)

31 Ginger extract (Zingiber officinale)

Size: $(34 \mathrm{~nm})$, shape: Particle characteristics Reference

(1-5 mL) of extract was photoluminescence, TEM spherical and irregular $\mathrm{AgNO}_{3}(20 \mathrm{mM})$ extract: $\quad$ UV-vis, DLS, EDX, TEM

Size: (19 nm), shape: 91 spherical

$\mathrm{AgNO}_{3}(10 \mathrm{mM})$ extract: UV-vis, FETEM, EDX, $\mathrm{AgNO}_{3}(1: 10) \mathrm{pH}: 10, \quad$ SAED, XRD, FTIR Size: $(12.6 \mathrm{~nm})$, shape: XRD, DLS, FTIR, UV-vis spherical

Size: $(30.25 \pm 5.26 \mathrm{~nm}), \quad 93$ crystalline

$\mathrm{AgNO}_{3}(0.5,1,3,10 \mathrm{mM}) \mathrm{XRD}$, TEM, UV-vis, DLS, Size: (30 to $\left.70 \mathrm{~nm}\right)$, shape: 94 100, 500 and $1000 \mathrm{mg}$ of UV-vis, TEM, EDX, XRD, Size: (31 and $40 \mathrm{~nm}$ ), 95 CBP added to $50 \mathrm{~mL}$ of zeta potential

$1 \mathrm{mM}$ aqueous $\mathrm{AgNO}_{3}$ quasi-spherical, and small, rod-shaped

solution and incubated in the dark at $25^{\circ} \mathrm{C}$ and shaken at $160 \mathrm{rpm}$. For CBPE, $1,2.5$ and $5 \mathrm{~mL}$ extract added to $50 \mathrm{~mL}$ of $1 \mathrm{mM}$ aqueous $\mathrm{AgNO}_{3}$ solution $\mathrm{AgNO}_{3}(1 \mathrm{mM})$, extract: UV-vis, FTIR, XRD, SEM- Size: (30 to $60 \mathrm{~nm}$ ) 96 $\mathrm{AgNO}_{3}$ solution $(1: 19), \quad$ EDX, TEM, zeta potential heat from $30{ }^{\circ} \mathrm{C}$ to $95{ }^{\circ} \mathrm{C}$ for $10 \mathrm{~min}$

$\mathrm{AgNO}_{3}(1 \mathrm{mM})$, extract: UV-vis, TEM, DLS, XRD, Size: $(12$ to $50 \mathrm{~nm})$, shape: 97 $\mathrm{AgNO}_{3}$ solution $(1: 10), \quad$ FTIR crystalline and spherical keep at $25{ }^{\circ} \mathrm{C}$ $\mathrm{AgNO}_{3}(1 \mathrm{mM})$, extract: $\quad$ UV-vis, FTIR, XRD, SEM, Size: (40 to $\left.50 \mathrm{~nm}\right)$, FCC 98 $\mathrm{AgNO}_{3}$ solution (1:19), TEM, EDAX structure pH: (6 to 7$)$ $\mathrm{AgNO}_{3}(0.1 \mathrm{M})$, extract: $\quad$ FTIR, UV-vis, TEM $\quad$ Size: (9 to $23 \mathrm{~nm}$ ), shape: 99 $\mathrm{AgNO}_{3}$ solution $(2: 1)$, heated at $60{ }^{\circ} \mathrm{C}$

100, 500 and $1000 \mathrm{mg}$ of UV-vis, TEM, XRD Size: $(21$ and $30 \mathrm{~nm}) \quad 100$ CLP added to $50 \mathrm{~mL}$ of $1 \mathrm{mM}$ aqueous $\mathrm{AgNO}_{3}$ solution and incubated in the dark at $25{ }^{\circ} \mathrm{C}$ in a rotary shaker at $160 \mathrm{rpm} .1,2.5$ and $5 \mathrm{~mL}$ extract added to $50 \mathrm{~mL}$ of $1 \mathrm{mM}$ aqueous $\mathrm{AgNO}_{3}$ solution

Nontoxic to VSMCs and NIH 3T3 fibroblasts

Antibacterial activity against Escherichia coli,
$\mathrm{AgNO}_{3}(0.98 \mathrm{mM})$, extract TEM, UV-vis, EDX, ATR- Size: $(4$ to $6 \mathrm{~nm})$ solution $(1.0 \mathrm{~mL}$ to $2.5 \quad$ FTIR, zeta potential, $\mathrm{mL}$ ) added to $51 \mathrm{~mL}$ of HPLC $\mathrm{AgNO}_{3}$ solution

$\mathrm{AgNO}_{3}(1 \mathrm{mM})$ extract UV-vis, XRD (20\%): $\mathrm{AgNO}_{3}$ solution
Size: $(2.89 \mathrm{~nm})$, shape: 102 spherical 
Table 2 (Contd.)

\begin{tabular}{|c|c|c|c|c|c|c|}
\hline $\begin{array}{l}\text { S. } \\
\text { no. }\end{array}$ & $\begin{array}{l}\text { Reducing agents (green } \\
\text { sources) }\end{array}$ & Applications & Operating conditions & $\begin{array}{l}\text { Characterization } \\
\text { techniques used }\end{array}$ & Particle characteristics & Reference \\
\hline & & $\begin{array}{l}\text { Klebsiella pneumoniae, } \\
\text { Pseudomonas aeruginosa, } \\
\text { Bacillus cereus and } \\
\text { Proteus vulgaris }\end{array}$ & $\begin{array}{l}(1: 9), \text { temperature }(27 \pm \\
\left.2^{\circ} \mathrm{C}\right)\end{array}$ & & & \\
\hline 32 & $\begin{array}{l}\text { Aqueous seed extract of } \\
\text { Manilkara zapota (L.) }\end{array}$ & $\begin{array}{l}\text { Antimicrobial activity } \\
\text { against Candida species }\end{array}$ & $\begin{array}{l}\text { 10\% concentration of } \\
\mathrm{MZSE} \text { was added to } \\
0.01 \mathrm{M} \mathrm{AgNO}_{3} \text {, heated at } \\
80{ }^{\circ} \mathrm{C}\end{array}$ & $\begin{array}{l}\text { EDX, DLS, TEM, XRD, } \\
\text { UV-vis }\end{array}$ & Size: $(40$ to $100 \mathrm{~nm})$ & 103 \\
\hline 33 & Leaf extract of avocado & Antibacterial activity & $\begin{array}{l}\mathrm{AgNO}_{3}(5 \mathrm{mM}) \text {, extract: } \\
\mathrm{AgNO}_{3} \text { solution }(1: 9), \\
\text { kept in the dark for } 24 \mathrm{~h}\end{array}$ & FTIR, XRD, SEM, UV-vis & $\begin{array}{l}\text { Size: }(35.6 \mathrm{~nm}) \text {, shape: } \\
\text { spherical }\end{array}$ & 104 \\
\hline 34 & $\begin{array}{l}\text { Origanum vulgare L. plant } \\
\text { extract }\end{array}$ & Antimicrobial activity & $\begin{array}{l}\mathrm{AgNO}_{3}(0.5 \mathrm{mM}), 1 \mathrm{~mL} \text { of } \\
\text { plant extract added to } \\
49 \mathrm{~mL} \text { of } \mathrm{AgNO}_{3} \text { solution } \\
\text { and stirred for } 2 \mathrm{~h} \text { at } 85- \\
90{ }^{\circ} \mathrm{C}\end{array}$ & $\begin{array}{l}\text { FTIR, UV-vis, XRD, TEM, } \\
\text { EDX }\end{array}$ & $\begin{array}{l}\text { Size: }(12 \mathrm{~nm}), \text { FCC } \\
\text { structure }\end{array}$ & 105 \\
\hline 35 & $\begin{array}{l}\text { Root extract of Croton } \\
\text { sparsiflorus }\end{array}$ & Antimicrobial activity & $\mathrm{AgNO}_{3}(1 \mathrm{M})$ & UV-vis, SEM & $\begin{array}{l}\text { Size: }(30 \text { to } 50 \mathrm{~nm}) \text {, shape } \\
\text { spherical }\end{array}$ & 106 \\
\hline 36 & $\begin{array}{l}\text { Roots extract of Coleus } \\
\text { forskohlii }\end{array}$ & Antimicrobial activity & $\begin{array}{l}\mathrm{AgNO}_{3}(1 \mathrm{mM}) \text {, extract: } \\
\mathrm{AgNO}_{3} \text { solution }(1: 20), \\
\text { incubated for } 24 \mathrm{~h} \text { at } 28 \\
{ }^{\circ} \mathrm{C}\end{array}$ & $\begin{array}{l}\text { UV-vis, EDS, FTIR, SEM, } \\
\text { XRD }\end{array}$ & $\begin{array}{l}\text { Size: }(82.46 \mathrm{~nm}) \text {, shape: } \\
\text { needle }\end{array}$ & 107 \\
\hline 37 & Lemon leaf extract & Antimicrobial activity & $\begin{array}{l}\mathrm{AgNO}_{3}(2 \mathrm{mM}) \text {, extract: } \\
\mathrm{AgNO}_{3} \text { solution }(1: 9), \\
\text { keep in the dark at room } \\
\text { temp }\end{array}$ & $\begin{array}{l}\text { FTIR, UV-vis, TEM, SEM, } \\
\text { AFM }\end{array}$ & $\begin{array}{l}\text { Size: (Smaller than } \\
100 \text { nm range), shape: } \\
\text { multi-shaped }\end{array}$ & 109 \\
\hline 38 & Banana peel extract & Antimicrobial activity & $\begin{array}{l}\mathrm{AgNO}_{3}(1.75 \mathrm{mM}) \\
\text { extract: } \operatorname{AgNO}_{3}(1: 50(\mathrm{v} / \\
\mathrm{v}))\end{array}$ & UV-vis, XRD, SEM, EDX & $\begin{array}{l}\text { Size: }(23.7 \mathrm{~nm}) \text {, } \\
\text { crystalline }\end{array}$ & 110 \\
\hline 39 & $\begin{array}{l}\text { Valerian officinalis } \\
\text { aqueous extract }\end{array}$ & & $\begin{array}{l}\mathrm{AgNO}_{3}(5 \mathrm{mM}), \text { plant } \\
\text { powder }(0.25,0.50,0.75 \\
\text { and } 1.0 \mathrm{~g}) 50 \mathrm{~mL} \text { distilled } \\
\text { water }\end{array}$ & UV-vis, XRD, SEM, TEM & $\begin{array}{l}\text { Size: }(22 \mathrm{~nm}) \text {, shape: } \\
\text { spherical, crystalline }\end{array}$ & 111 \\
\hline 40 & $\begin{array}{l}\text { Tectona grandis seed } \\
\text { extract }\end{array}$ & $\begin{array}{l}\text { Antimicrobial activity } \\
\text { against microorganisms }\end{array}$ & $\begin{array}{l}\mathrm{AgNO}_{3}(1 \mathrm{mM}) \\
\mathrm{AgNO}_{3}: \text { seed extract }(1: 9)\end{array}$ & $\begin{array}{l}\text { UV-visible XRD, FTIR } \\
\text { SEM/EDS, FESEM, TEM }\end{array}$ & $\begin{array}{l}\text { Size: }(10 \text { to } 30 \mathrm{~nm}) \text {, shape: } \\
\text { spherical, crystalline }\end{array}$ & 112 \\
\hline 41 & $\begin{array}{l}\text { Extracts of Ananas } \\
\text { comosus }\end{array}$ & & $\begin{array}{l}\mathrm{AgNO}_{3}(10 \mathrm{mM}) \\
\text { pineapple juice: } \mathrm{AgNO}_{3} \\
(1: 10)\end{array}$ & XRD, UV-vis, EDAX, TEM & $\begin{array}{l}\text { Size: }(12 \mathrm{~nm}), \text { FCC } \\
\text { crystalline }\end{array}$ & 113 \\
\hline 42 & $\begin{array}{l}\text { Extract of saffron (Crocus } \\
\text { sativus L.) }\end{array}$ & Antibacterial activity & $\begin{array}{l}\mathrm{AgNO}_{3}(2 \mathrm{mM}) \text {, extract: } \\
\mathrm{AgNO}_{3} \text { solution }(1: 4)\end{array}$ & UV-vis, FTIR, XRD, TEM & $\begin{array}{l}\text { Size: }(15 \mathrm{~nm}) \text {, shape: } \\
\text { spherical }\end{array}$ & 114 \\
\hline 43 & $\begin{array}{l}\text { Onion (Allium cepa) } \\
\text { extract }\end{array}$ & Antibacterial activity & $\begin{array}{l}\mathrm{AgNO}_{3}(0.1 \mathrm{mM}) \text {, extract: } \\
\mathrm{AgNO}_{3} \text { solution }(1: 10), \\
\text { constant stirring at } 50-60 \\
{ }^{\circ} \mathrm{C}\end{array}$ & UV-vis, DLS, TEM & $\begin{array}{l}\text { Size: }(33.6 \mathrm{~nm}) \text {, shape: } \\
\text { spherical }\end{array}$ & 115 \\
\hline 44 & $\begin{array}{l}\text { Thymus kotschyanus plant } \\
\text { extract }\end{array}$ & $\begin{array}{l}\text { Antioxidant, antibacterial } \\
\text { and cytotoxic effects }\end{array}$ & $\begin{array}{l}\mathrm{AgNO}_{3}(1 \mathrm{mM}) \text {, extract: } \\
\mathrm{AgNO}_{3}(1: 10) \text {, stir for } \\
30 \mathrm{~min} \text { in the dark }\end{array}$ & $\begin{array}{l}\text { UV-vis, FTIR, EDX, XRD, } \\
\text { TGA, SEM, TEM, AFM }\end{array}$ & Size: $(50$ to $60 \mathrm{~nm})$ & 116 \\
\hline 45 & D. carota (carrot) extract & & $\begin{array}{l}\mathrm{AgNO}_{3}(0.5 \mathrm{mM}), \text { extract: } \\
\mathrm{AgNO}_{3}(1: 6)\end{array}$ & $\begin{array}{l}\text { XRD, UV-visible FTIR, } \\
\text { TEM }\end{array}$ & $\begin{array}{l}\text { Size: }(20 \mathrm{~nm}) \text {, shape: } \\
\text { spherical }\end{array}$ & 117 \\
\hline 46 & $\begin{array}{l}\text { Garcinia mangostana } \\
\text { stem aqueous extract }\end{array}$ & Antimicrobial activity & $\begin{array}{l}\mathrm{AgNO}_{3}(1 \mathrm{mM}), \text { extract: } \\
\mathrm{AgNO}_{3}(3: 17)\end{array}$ & UV-vis, XRD, SEM, EDX & Size: $(30 \mathrm{~nm})$ & 118 \\
\hline 47 & Olive leaf extract & Antibacterial activity & $\begin{array}{l}\mathrm{AgNO}_{3}(1 \mathrm{mM}) \text {, extract }(2- \\
9 \mathrm{~mL}) \text { added to } \mathrm{AgNO}_{3} \\
\text { solution }\end{array}$ & $\begin{array}{l}\text { TEM, UV-vis, FTIR, TG, } \\
\text { XRD }\end{array}$ & $\begin{array}{l}\text { Size: ( } 20 \text { to } 25 \mathrm{~nm} \text { ), shape: } \\
\text { spherical }\end{array}$ & 119 \\
\hline 48 & $\begin{array}{l}\text { Extract of Chenopodium } \\
\text { ambrosioides }\end{array}$ & & $\begin{array}{l}\mathrm{AgNO}_{3}(1 \mathrm{mM} \text { and } 10 \\
\mathrm{mM}) \text {, extract: } \mathrm{AgNO}_{3}(0.5 \\
1,2,3 \text { and } 5 \mathrm{~mL}: 5)\end{array}$ & UV-vis, TEM, FTIR & Size: $(4.9 \pm 3.4 \mathrm{~nm}), \mathrm{FCC}$ & 120 \\
\hline 49 & $\begin{array}{l}\text { Aqueous leaf extract of } \\
\text { Acalypha indica }\end{array}$ & $\begin{array}{l}\text { Antifungal effect against } \\
\text { Phytopathogen } \\
\text { Colletotrichum capsici }\end{array}$ & $\begin{array}{l}\mathrm{AgNO}_{3}(1 \mathrm{mM}), \text { extract: } \\
\mathrm{AgNO}_{3}(1: 9) \text {, incubate at } \\
37^{\circ} \mathrm{C}\end{array}$ & UV-vis, antifungal & & 121 \\
\hline 50 & Ficus benghalensis leaf & Antibacterial activity & & UV-vis, TEM-EDX, XRD & & 122 \\
\hline
\end{tabular}
extract 
Table 2 (Contd.)

\begin{tabular}{|c|c|c|c|c|c|c|}
\hline $\begin{array}{l}\text { S. } \\
\text { no. }\end{array}$ & $\begin{array}{l}\text { Reducing agents (green } \\
\text { sources) }\end{array}$ & Applications & Operating conditions & $\begin{array}{l}\text { Characterization } \\
\text { techniques used }\end{array}$ & Particle characteristics & Reference \\
\hline 51 & $\begin{array}{l}\text { Litchi chinensis leaf } \\
\text { methanolic extract }\end{array}$ & $\begin{array}{l}\text { Strong muscle relaxant, } \\
\text { analgesic and anti- } \\
\text { inflammatory activities }\end{array}$ & $\begin{array}{l}\mathrm{AgNO}_{3}(1 \mathrm{M}), \text { extract: } \\
\mathrm{AgNO}_{3}(1: 1 \text { and } 1: 10)\end{array}$ & UV-vis & & 123 \\
\hline 52 & $\begin{array}{l}\text { Salvia leriifolia leaf } \\
\text { extract }\end{array}$ & $\begin{array}{l}\text { Antibacterial activity } \\
\text { against } 9 \text { bacteria }\end{array}$ & $\begin{array}{l}\mathrm{AgNO}_{3}(1 \mathrm{mM}), \text { extract: } \\
\mathrm{AgNO}_{3}(1: 24)\end{array}$ & SEM, AFM, XRD, FTIR & $\begin{array}{l}\text { Size: }(27 \mathrm{~nm}) \text {, shape: } \\
\text { pherical }\end{array}$ & 124 \\
\hline 53 & $\begin{array}{l}\text { Glycyrrhiza glabra root } \\
\text { extract }\end{array}$ & Treatment of gastric ulcer & $\begin{array}{l}\mathrm{AgNO}_{3}(1 \mathrm{mM}) \text {, extract: } \\
\mathrm{AgNO}_{3}(1: 49)\end{array}$ & UV-vis, TEM, XRD, FTIR & Size: (19 nm), crystalline & 125 \\
\hline 54 & $\begin{array}{l}\text { Pimpinella anisum seed } \\
\text { extract }\end{array}$ & $\begin{array}{l}\text { Antimicrobial activity } \\
\text { and cytotoxicity on } \\
\text { human neonatal skin } \\
\text { stromal cells and colon } \\
\text { cancer cells }\end{array}$ & $\begin{array}{l}\mathrm{AgNO}_{3}(3 \mathrm{mM}) \text {, extract: } \\
\mathrm{AgNO}_{3}(1: 100)\end{array}$ & $\begin{array}{l}\text { UV-vis, FTIR, XRD, EDX, } \\
\text { TEM }\end{array}$ & Size: $(15 \mathrm{~nm})$ & 126 \\
\hline 55 & $\begin{array}{l}\text { Glycyrrhiza uralensis root } \\
\text { extract }\end{array}$ & $\begin{array}{l}\text { Antimicrobial agent } \\
\text { against Escherichia coli, } \\
\text { Staphylococcus aureus, } \\
\text { Pseudomonas aeruginosa } \\
\text { and Salmonella enterica }\end{array}$ & $\begin{array}{l}\mathrm{AgNO}_{3}(1 \mathrm{mM}) \text {, extract: } \\
\mathrm{AgNO}_{3}(1: 1) \text {, heated in } \\
\text { oil bath at } 80{ }^{\circ} \mathrm{C} \text {, change } \\
\text { in color is observed }\end{array}$ & $\begin{array}{l}\text { UV-vis, TEM, SAED, XRD, } \\
\text { DLS, FTIR }\end{array}$ & $\begin{array}{l}\text { Size: (5 to } 15 \mathrm{~nm} \text { ), shape: } \\
\text { spherical }\end{array}$ & 127 \\
\hline 56 & Orange peel & Antimicrobial activity & $\begin{array}{l}\mathrm{AgNO}_{3}(1 \mathrm{mM}) \\
\text { AgNO}_{3} \text { :orange peel } \\
\text { extract }(1: 1), \mathrm{pH} \text { above } 7\end{array}$ & $\begin{array}{l}\text { UV-vis, FTIR, DLS, XRD, } \\
\text { zeta potential, TEM }\end{array}$ & Size: $(48.1 \pm 20.5 \mathrm{~nm})$ & 128 \\
\hline 57 & $\begin{array}{l}\text { Citrus recticulata fruit } \\
\text { peel extract }\end{array}$ & $\begin{array}{l}\text { Antibacterial activity } \\
\text { against Streptococcus } \\
\text { pyogenes, Staphylococcus } \\
\text { aureus, Bacillus subtilis, } \\
\text { Escherichia coli, } \\
\text { Salmonella Paratyphi and } \\
\text { Klebsiella pneumoniae }\end{array}$ & $\begin{array}{l}\mathrm{AgNO}_{3}(1 \mathrm{mM}), \text { extract: } \\
\mathrm{AgNO}_{3}(1: 20)\end{array}$ & $\begin{array}{l}\text { UV-vis, FTIR, XRD, SEM, } \\
\text { EDX }\end{array}$ & Size: $(24 \mathrm{~nm})$ & 129 \\
\hline
\end{tabular}

reported morphological and molecular methods to synthesize AgNPs under optimized conditions, i.e., the substrate concentration of $1.5 \mathrm{mM}$, alkaline $\mathrm{pH}$, reaction temperature of $55^{\circ} \mathrm{C}$, and reaction time of $10 \mathrm{~h}$, utilizing the fungal strain of Arthroderma fulvum. The synthesized AgNPs were found to be crystalline in nature and the particle size was optimized to be $\sim 15.5$ $\pm 2.5 \mathrm{~nm}$. Antifungal activity was observed against fungal strains, including Candida, Fusarium, and Aspergillus. ${ }^{\mathbf{1 4 6}}$ Honary S. et al. (2013) evaluated a green synthetic method for the extracellular production of AgNPs using Penicillium citrinum isolated from soil. The synthesized NPs were found to be spherical in shape with an average diameter of $109 \mathrm{~nm} \cdot{ }^{\mathbf{1 4 7}} \mathrm{A}$

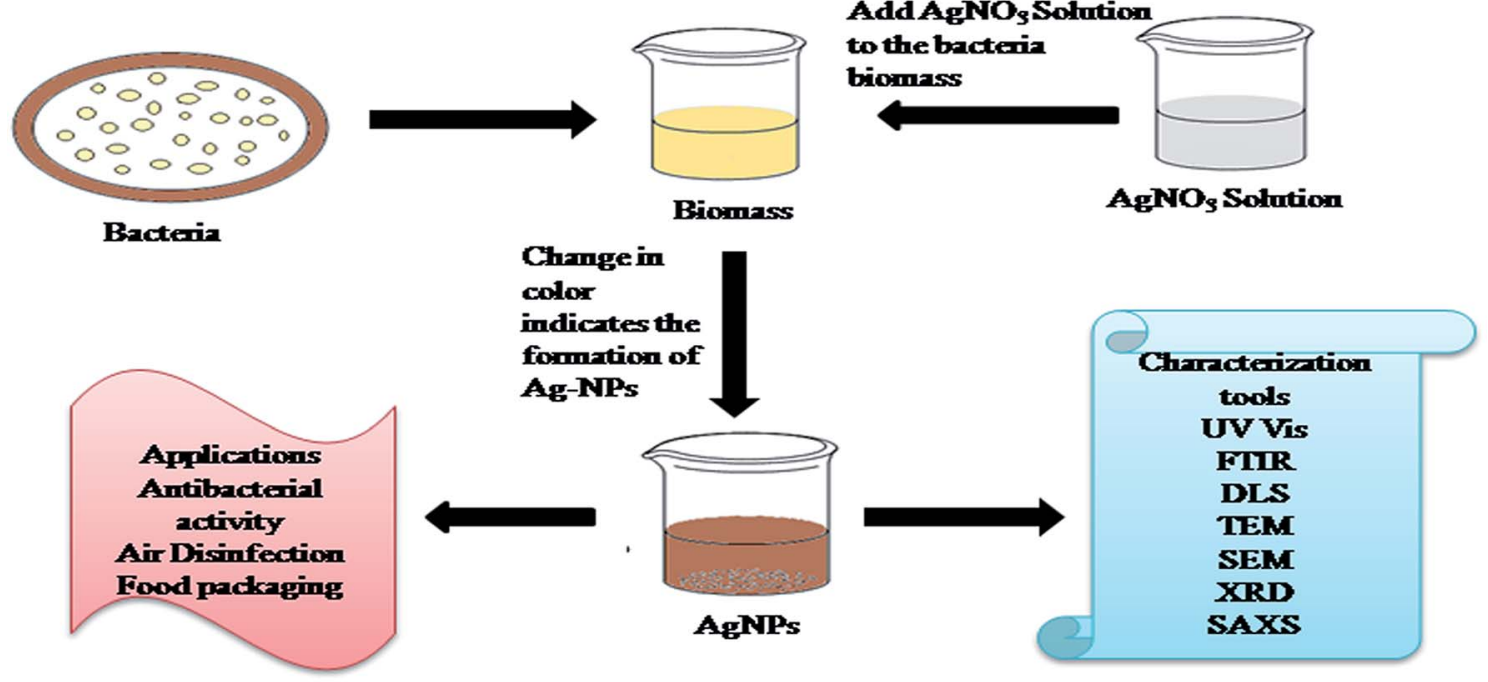

Fig. 3 Mechanism for the green synthesis of AgNPs from bacteria. 
Table 3 Synthetic conditions, applications, size and characterization techniques for AgNPs using various strains of bacteria

\begin{tabular}{|c|c|c|c|c|c|c|}
\hline $\begin{array}{l}\text { S. } \\
\text { no. }\end{array}$ & Bacteria & Application & Conditions & Characterization & Size & Reference \\
\hline 1 & Psychrophilic bacteria & $\begin{array}{l}\text { Stable for } 8 \text { months in the } \\
\text { dark }\end{array}$ & $\begin{array}{l}1 \mathrm{~mL} \text { of } 1 \mathrm{mM} \mathrm{AgNO} \mathrm{Al}_{3} \text { was } \\
\text { added to } 25 \mathrm{mg} \text { of the } \\
\text { washed cell, and incubated } \\
\text { under a fluorescent lamp } \\
(\mathrm{CFL}) \text { of } 9 \mathrm{~W}\end{array}$ & $\begin{array}{l}\text { UV-vis spectroscopy, } \\
\text { transmission electron } \\
\text { microscopy, atomic force } \\
\text { microscopy }\end{array}$ & Size: (6 to $13 \mathrm{~nm}$ ) & 136 \\
\hline 2 & $\begin{array}{l}\text { Endophytic bacterium, } \\
\text { Pantoea ananatis }\end{array}$ & $\begin{array}{l}\text { Antimicrobial against } \\
\text { multi-drug resistant } \\
\text { bacteria }\end{array}$ & $\begin{array}{l}\text { Reaction mixture of cell } \\
\text { free extract and } 100 \mathrm{~mL} \text { of } \\
0.1 \mathrm{mM} \mathrm{AgNO} \text { solution } \\
(2 \%, \mathrm{v} / \mathrm{v}) \text { exposed to bright } \\
\text { sunlight, } \mathrm{pH}(7)\end{array}$ & $\begin{array}{l}\text { UV-vis, TEM, SEM, FTIR, } \\
\text { zeta potential }\end{array}$ & $\begin{array}{l}\text { Size: (8.06 to } 91.32 \\
\mathrm{~nm})\end{array}$ & 137 \\
\hline 3 & $\begin{array}{l}\text { Culture supernatant of } \\
\text { Klebsiella pneumonia }\end{array}$ & & $\begin{array}{l}\mathrm{AgNO}_{3}(1 \mathrm{mM}) \\
\text { supernatant } 1 \%(\mathrm{v} / \mathrm{v})\end{array}$ & XRD, UV-vis, TEM, EDS & Size: $(3 \mathrm{~nm})$ & 139 \\
\hline 4 & $\begin{array}{l}\text { Culture supernatants of } \\
\text { Enterobacteriaceae }\end{array}$ & & $\begin{array}{l}\mathrm{AgNO}_{3}(1 \mathrm{mM}), \\
\text { supernatant }(1 \%, \mathrm{v} / \mathrm{v})\end{array}$ & UV-vis, EDS, TEM & Size: $(52.5 \mathrm{~nm})$ & 141 \\
\hline 5 & $\begin{array}{l}\text { Biomass of bacterial } \\
\text { exopolysaccharide }\end{array}$ & $\begin{array}{l}\text { Used in degradation of azo } \\
\text { dye }\end{array}$ & $\mathrm{AgNO}_{3},(9 \mathrm{mM})$ & $\begin{array}{l}\text { UV-vis, TEM, SEM, AFM, } \\
\text { XRD, TGA-DTA, Raman } \\
\text { spectroscopy }\end{array}$ & $\begin{array}{l}\text { Size: }(35 \mathrm{~nm}), \\
\text { shape: spherical }\end{array}$ & 143 \\
\hline
\end{tabular}

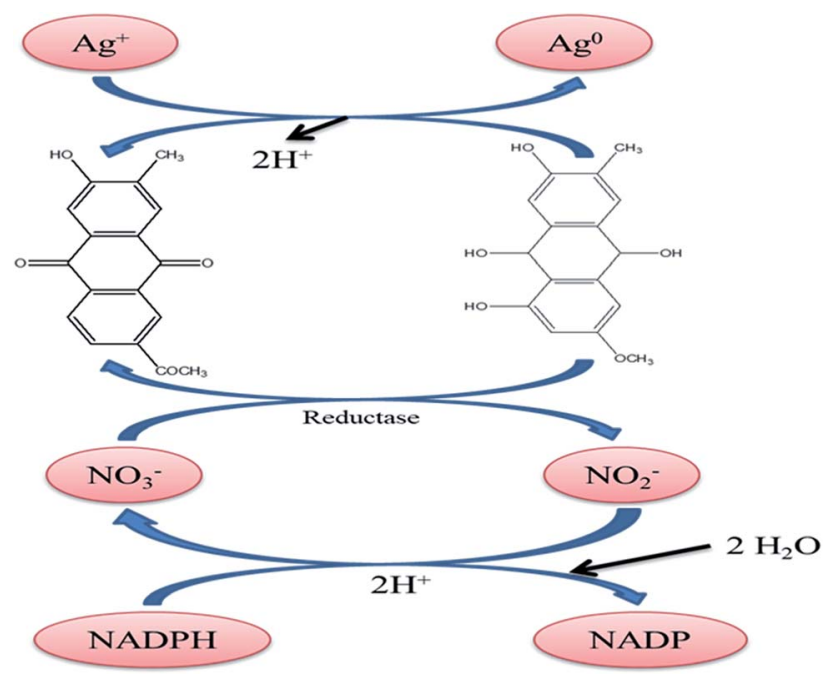

Fig. 4 Mechanism for the synthesis of AgNPs using fungi.

controlled and up-scalable green method for the synthesis of AgNPs with a well-defined morphology utilizing the cell-free aqueous filtrate of a non-pathogenic and suitable biocontrol agent Trichoderma asperellum was reported for the first time. ${ }^{148}$ Verma VC et al. (2010) prepared AgNPs utilizing Aspergillus clavatus and demonstrated their antimicrobial potential. ${ }^{149}$ AgNPs were synthesized by Li G. et al. (2012) using culture supernatants of Aspergillus terreus for the reduction of $\mathrm{Ag}$ ions. ${ }^{150}$

Subashini G. and Bhuvaneswari S. (2018) reported the synthesis of AgNPs from fungi and their applications in various fields of biology. ${ }^{151}$ AgNPs synthesized using Fusarium oxysporum were optimized by Birla SS et al. (2013) using different media, $\mathrm{pH}$, temperature, light intensity, filtrate volume, salt concentration, and quantity of biomass. ${ }^{152}$ Neethu S. et al. (2018) reported the extracellular green synthesis of AgNPs utilizing the biomass of Penicillium polonium. ${ }^{153}$ Khan MN et al. (2015) utilized aqueous Raphanussativus root extract as a reducing and capping agent for the synthesis of silver nanomaterials for the first time. ${ }^{154} \mathrm{Ma}$ L. et al. (2017) utilized the supernatant of the fungus strain Penicillium aculeatum Su1 to synthesize extracellular AgNPs. ${ }^{155} \mathrm{Al}-\mathrm{Bahrani}$ R. et al. (2017) reported the green synthesis of AgNPs utilizing the aqueous extract of basidiocarps of oyster mushroom, Pleurotus stratus ${ }^{\mathbf{1 5 6}}$. Jalal M. et al. (2018) studied the extracellular green synthesis of AgNPs using the supernatant of Candida glabrata isolated from oropharyngeal mucosa of human immunodeficiency virus (HIV) patients and evaluated them for antibacterial and antifungal potential against human pathogenic bacteria and fungi. ${ }^{157}$ Eugenio M. et al. (2016) reported the biosynthesis of Ag NPs using yeast strains. ${ }^{158}$ Otari SV et al. (2014) synthesized AgNPs utilizing the culture supernatant of phenol degraded broth as the reducing agent. ${ }^{159}$ Ishida K. et al. (2014) studied the synthesis and antifungal activity of AgNPs synthesized utilizing the aqueous extract of the fungus Fusarium oxysporum. ${ }^{160}$ More details on the synthesis of AgNPs from fungi and yeast are discussed in Table 4.

\subsection{Green synthesis of AgNPs using biopolymers}

Nearly all of the wide varieties of biopolymers used for the synthesis of AgNP play the dual role of reducing and stabilizing agent except for the use of starch as a capping agent. ${ }^{163}$ Fig. 5 presents the synthesis of AgNPs from various sources of biopolymers. Leung TC et al. (2010) synthesized AgNPs within 10-15 min by utilizing carboxymethylated-curdlan or fucoidan as reducing and stabilizing agents. Heating the reaction mixture at $100{ }^{\circ} \mathrm{C}$ led to the formation of AgNPs with a size in the range of $40-80 \mathrm{~nm} .{ }^{164}$ Regiel Futyra A et al. (2017) reported that biopolymers enhanced the antimicrobial activity of AgNPs. Chitosan and ascorbic acid were utilized as the reducing and capping agent, respectively, for the synthesis of AgNPs with 
Table 4 Synthetic conditions, applications, size and characterization techniques for the synthesis of AgNPs using various strains of fungi

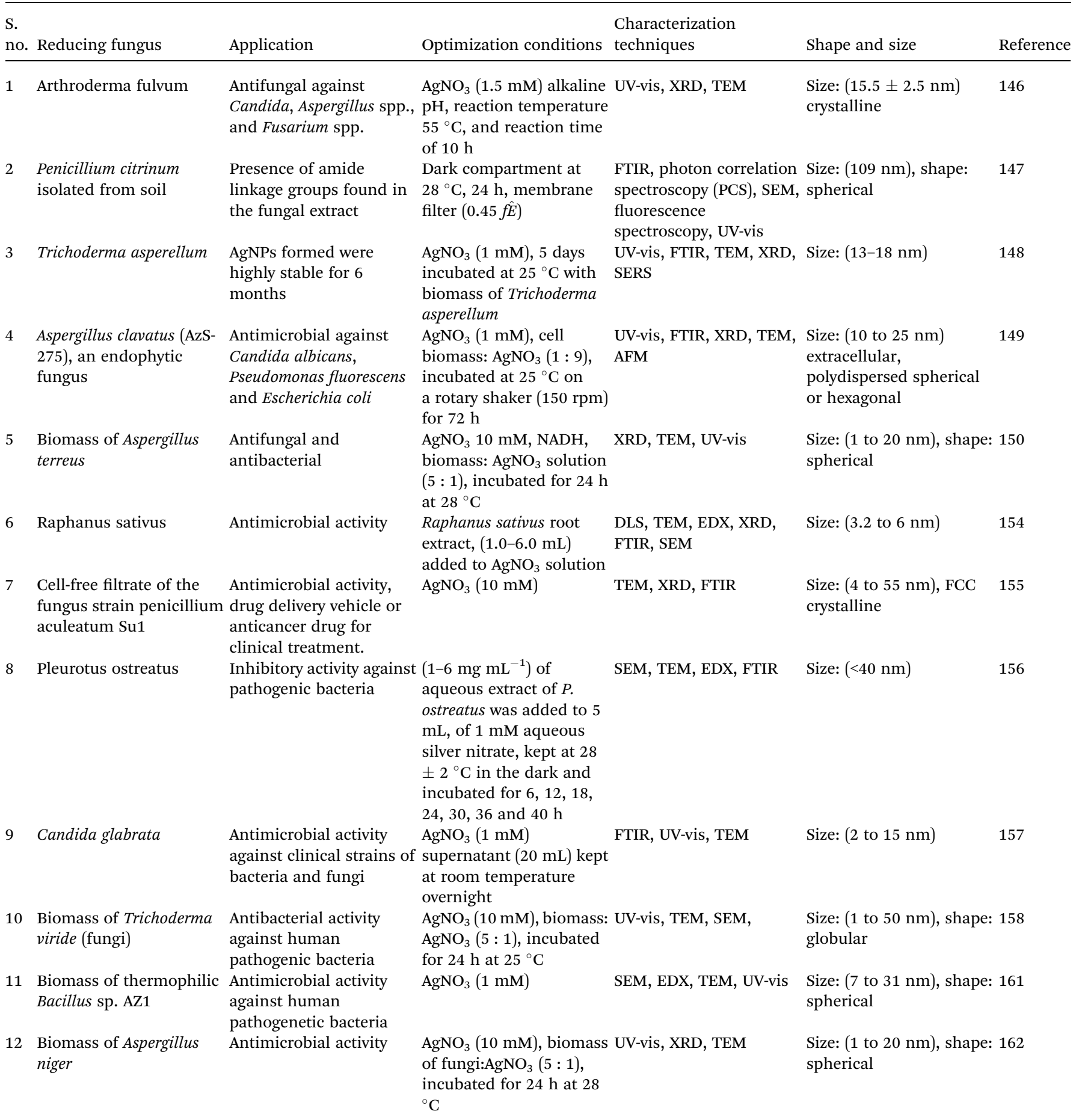

a size smaller than $10 \mathrm{~nm} .{ }^{\mathbf{1 6 5}}$ Biogenic AgNPs were synthesized using Nigella sativa extract (NSE), which exhibited potential antioxidant activity. The TEM image showed biphasic spherical AgNPs with an average particle size of $8 \mathrm{~nm}$. The effect of the AgNPs on the sustained release and film-forming capacity of chitosan was then evaluated. ${ }^{\mathbf{1 6 6}}$ Ahmad MB et al. (2011) synthesized AgNPs in an aqueous medium. The reduction of $\mathrm{AgNO}_{3}$ was carried out using chitosan and polyethylene glycol (PEG). PEG and chitosan were utilized as the polymeric stabilizer and solid support, respectively. ${ }^{167}$ Vasileva et al. (2011) synthesized stable and uniform starch-stabilized silver NPs with an average diameter of $14.4 \pm 3.3 \mathrm{~nm}$ using ultrasoundmediated silver nitrate reduction by D-glucose. UV-vis spectroscopy, HR-TEM, XRD, TG/DTA, and DSC were used to characterize the starch-stabilized silver NPs completely. These NPs exhibited catalytic activity for the reduction of $\mathrm{H}_{2} \mathrm{O}_{2}$. Induced by the catalytic decomposition of $\mathrm{H}_{2} \mathrm{O}_{2}$, the degradation of the AgNPs caused a significant change in the absorbance strength 


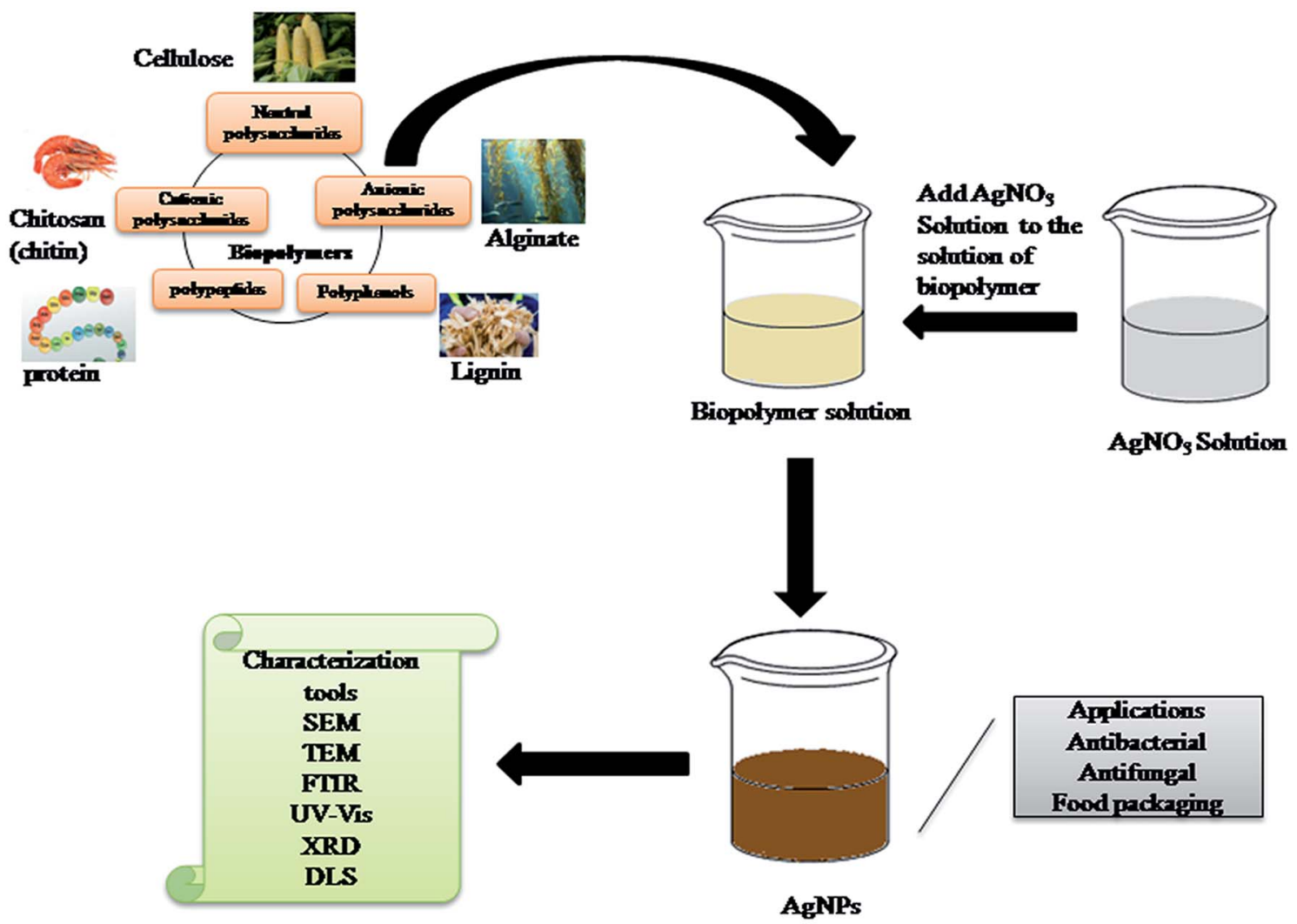

Fig. 5 Procedure for the synthesis of AgNPs using biopolymers.

of the localized surface resonance band depending on the concentration of $\mathrm{H}_{2} \mathrm{O}_{2}$. Subsequently, the optical sensor based on improvised plasmon resonance was characterized and calibrated. Good sensitivity and a linear response over the wide concentration range of $10^{-1}$ to $10^{-6} \mathrm{~mol} \mathrm{~L}^{-1} \mathrm{H}_{2} \mathrm{O}_{2}$ were established. ${ }^{168}$

Atta A et al. (2014) reported a green synthetic method involving the reduction of $\mathrm{Ag}^{+}$ions in aqueous acidic solution in the presence of polyvinyl alcohol modified with thiol groups (PVA-SH). AgNPs were stabilized by coating different types of citrate-reduced AgNPs with different weight ratios of PVSH derivatives (1-3 wt\%). The as-prepared AgNPs were characterized via UV-vis spectroscopy, TEM/EDS, DLS and XRD combined with Rietveld analysis. The changes in the particle size, shape and hydrodynamic diameter of the AgNPs were determined using TEM, XRD and UV-visible spectroscopy after different durations of exposure to synthetic stomach fluid (SSF) and $1 \mathrm{M}$ $\mathrm{HCl}$. The data showed that for more than 90 days, these AgNPs were highly stable against SSF, which was not previously reported in the literature. ${ }^{169} \mathrm{Wu}$ Q. et al. (2008) synthesized glutathione-capped AgNPs with adjustable sizes. These particles could be bound covalently to other functional molecules and displayed sensitive optical properties to particle size and surface modification. The AgNPs with a diameter of $\sim 6 \mathrm{~nm}$ prevented the proliferation of human K562 cells with leukemia, implying their potential cancer activity. ${ }^{170}$ The procedure for the synthesis of AgNPs using biopolymers is shown in Fig. 5.
Si S. et al. (2007) synthesized AgNPs at pH 11 utilizing synthetic oligopeptides containing tryptophan residue at the Cterminus. The tryptophan residue in the peptides, possibly through electron transfer, is responsible for reducing metal ions to the respective metals. ${ }^{171}$ Oligopeptides based on $\mathrm{L}$-valine with the chemical structure $\mathrm{Z}-(\mathrm{L}-\mathrm{Val}) 3-\mathrm{OMe}$ and $\mathrm{Z}-(\mathrm{L}-\mathrm{Val}) 2-\mathrm{L}-$ Cys(S-Bzl)-OMe formed stable organogels in butanol. Both peptides are effective gelators, but they crystallize more readily than Z-(L-Val) 2-L-Cys(S-Bzl)-OMe. These two peptides are capable of forming mixed fibers, including gel butanol. The fibers can be mineralized using DMF as a reducing agent with AgNPs. The Z-(L-Val) 2-L-Cys(S-Bzl)-OMe fraction of the sulfurcontaining peptide controlled the shape and size of the resulting NPs. Small spherical particles were distributed throughout the fiber at a high Z-(L-Val) 2-L-Cys(S-Bzl)-OMe content. A lower Z-(L-Val) 2-L-Cys(S-Bzl)-OMe content led to an increase in particle size and more complex forms such as plate-like and silver-like raspberry particles. The interactions between peptide and silver ions or silver particles occur through the complexation of silver ions to the sulfur atom of the thioether moiety and were shown to be the key interaction in controlling the formation of the particles. ${ }^{172}$

Kasthuri J. et al. (2009) reported the synthesis of quasisphere AgNPs using apiine as the reduction and stabilization agent. The size and shape of the NPs could be controlled by varying the ratio of metal salts to apiine compound in the reaction medium. UV-vis-NIR, TEM, FTIR spectroscopy, XRD 
and TGA were used to characterize the synthesized NPs. The interaction between the NPs and the carbonyl group of the apiine compound was confirmed using FT-IR spectroscopy. The average size of the AgNPs was found to be $39 \mathrm{~nm}$ via TEM invetigation. ${ }^{173}$ Safaepour M. et al. (2009) synthesized evenly dispersed AgNPs with a uniform size and shape in the range of 1 to $10 \mathrm{~nm}$ using geraniol. The cytotoxicity analysis of the AgNPs showed a direct dose-response relationship, where higher concentrations resulted in increased cytotoxicity. The AgNPs were able to inhibit the growth of the Fibrosarcoma-Wehi 164 cell line by less than $30 \%$ at a concentration of $1 \mu \mathrm{g} \mathrm{mL}{ }^{-1} \cdot{ }^{174}$ The aqueous solution of AgNPs exhibited different SPR when prepared at different $\mathrm{pH}$ values. PEG was used as a reducing and stabilizing agent to synthesize AgNPs since it is ecofriendly, which produced monodispersed particles with a diameter of less than $10 \mathrm{~nm}$. The colloids exhibited activity against Grampositive and Gram-negative bacteria and fungi. Biodegradable starch played the role of a capping agent in the synthesis of AgNPs. The analysis showed that a starch layer was coated on NPs. The diameters of the particles ranged from 5-20 nm. XRD analysis showed the face-centered cubic structure of the NPs. In many fields of science, ion-exchangeable polymers act as capping agents. These often-used polymers contain phosphonic acid groups with a low molecular weight. Polymer complexation to $\mathrm{Ag}^{+}$occurs, and then the metal ions are reduced to NPs. In the presence of an ion-exchange polymer, AgNPs were stabilized. The morphology of the surface indicated the formation of cubes and rectangular prism structures. Copolymers such as CD, grafted with PAA, helped to synthesize AgNPs initiated by potassium persulfate. ${ }^{\mathbf{1 7 5}}$

Maity D. et al. (2011) used poly(methyl vinyl ether co maleic anhydride) (PVM/MA) as a reducing and capping agent. The synthesized NPs were stable for a month at room temperature and surrounded by 5-8 $\mathrm{nm}$ sheath of PVM/MA. ${ }^{176}$ A variety of factors influenced the formation of NPs, such as acidity, initial concentration of starting materials, and molar ratio of reactants. Some dispersing agents prevented the accumulation of NPs and helped in the analysis of morphology, particle size, composition of elements, etc. The NPs were non-aggregated, and possessed a face-centered cubic (FCC) structure, and spherical shape. Ascorbic acid or citrate was used to reduce ions, which resulted in an average particle size of approximately 10.2-13.7 $\mathrm{nm}$. The zeta potential ranged from $40-42 \mathrm{mV}$ and was primarily influenced by the acidity and size of the NPs. ${ }^{177}$ When reacted with ammonium hydroxide, formaldehyde produced a polymer that affected the way silver was bound to the substrate. In unfavorable conditions for the synthesis of the polymer, the NPs formed were concentrated and possessed a gold-silver plasmon resonance $(498 \mathrm{~nm}) .{ }^{177}$

\section{Synthetic mechanism and characteristics of AgNPs}

The synthesis of AgNPs can be carried out using natural sources such as carbohydrates, fat, phenols flavonoids, proteins, enzymes and coenzymes, terpenoids, gum, alkaloids, and sugars to reduce $\mathrm{Ag}^{+}$ions. Depending on the organism/extract used, the active ingredient responsible for the reduction of $\mathrm{Ag}^{+}$ions varies. Electrons are required for the nano transformation of AgNPs from acid (ascorbic acid) dehydrogenation and keto-enol conversion in mesophytes or both mechanisms in xerophyte plants. A similar reduction process can be performed by microbial cellular and extracellular oxidoreductase enzymes. The major constituents of fungi and bacteria such as quinones, NADH, nitroreductase enzyme, and proteins are responsible for the reduction and stabilization of AgNPs. It is assumed that the electrostatic interactions between the carboxylic group attached to the surface of fungal cell and $\mathrm{Ag}^{+}$ ions result in the formation of AgNPs, and proteins prevent the AgNPs from agglomerating. ${ }^{178}$ The major source of nitrogen used by bacteria is nitrate, which is reduced to nitrite by the enzyme nitrate reductase and NADH. This metabolic activity for the formation of ammonium and nitrile can be utilized in the green synthesis of AgNPs via the intracellular reduction of $\mathrm{Ag}^{+}$ ions. Proteins effectively prevent the agglomeration and increase in particle size caused by particle collisions, which maintain the high stability of colloidal AgNPs. ${ }^{155}$ Fig. 6 shows a schematic of the reaction mechanism for the synthesis of AgNPs from various sources. Based on the tautomerization in flavanoids, the possible mechanism for the synthesis of AgNPs is shown in Fig. 6(a). Fig. 6(b) presents the reaction mechanism for the synthesis of AgNPs involving the reduction of $\mathrm{Ag}^{+}$ions due to the oxidation of NADH to $\mathrm{NAD}^{+}$.

\subsection{Separation of AgNPs from suspension and their characterization}

Researchers mainly use the centrifugation technique to obtain the pellet or powder form of synthesized AgNPs. AgNPs suspensions have also been dried to obtain the product in powder form. Some common techniques for the characterization of AgNPs include UV-vis spectroscopy, SEM, TEM, FTIR, XRD, and EDAX. DLS study is used for AgNPs synthesized from bio-polymers rather than plant extracts and microorganisms. UV-visible spectroscopy is considered the primary characterization technique to monitor the synthesis and stability of synthesized AgNPs. Due to the unique optical properties of AgNPs, they show strong interaction with light at specific wavelengths. The band gap in AgNPs is very low, and as a result electrons move freely, causing an SPR band due to the collective oscillation of electrons of AgNPs in resonance with light. ${ }^{\mathbf{1 7 9 - 1 8 1}}$ Zeta potential values show the stability of synthesized AgNPs. Dubey et al. reported that AgNPs show a lower zeta potential value in acidic $\mathrm{pH}$, and higher values in more basic $\mathrm{pH}$ solutions. It was observed that the absorbance peak became sharp with an increase in reaction time. ${ }^{40}$ The XRD analysis of the AgNPs shows diffraction peaks at $38.13^{\circ}, 44.21^{\circ}$, $64.47^{\circ}, 77.37^{\circ}, 81.47^{\circ}, 98.01^{\circ}, 110.56^{\circ}$ and $114.80^{\circ}$, which confirms the FCC structure of AgNPs. ${ }^{40,43,93}$ XRD and EDAX study also confirm the purity of the synthesized AgNPs. FTIR analysis reveals the functional groups responsible for the reduction and stabilization of AgNPs. TM Nguyen et al. analyzed the presence of protein via FTIR in the seeds of Nelumbo nucifera. The synthesized spherical AgNPs using the seed extract of Nelumbo nucifera 
<smiles></smiles>

(b)

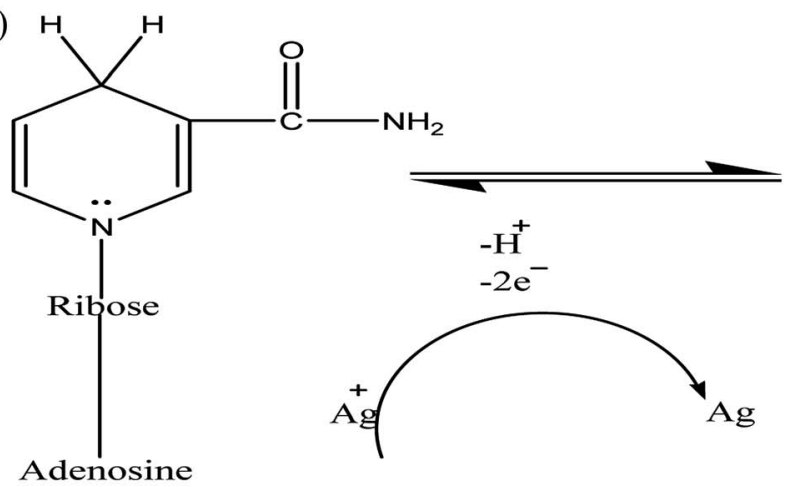

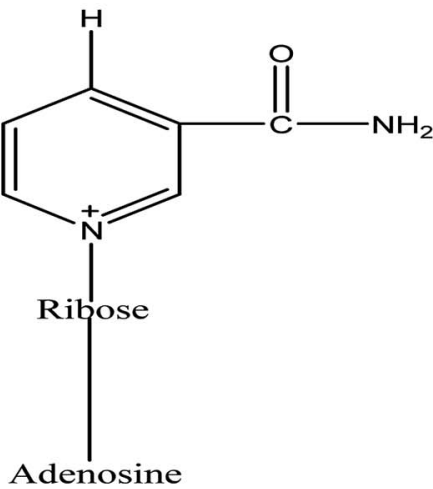

Fig. 6 (a) Reaction mechanism for the synthesis of AgNPs due to the flavanoids ${ }^{92}$ present in plant extract. (b) Reaction mechanism for the synthesis of AgNPs due to NADH present in fungi and bacteria.

showed cytotoxicity against Gram-negative bacteria. ${ }^{43}$ ZA Ali et al. reported that AgNPs synthesized using apple extract were stable due to the presence of the ethylene group in apple extract. These AgNPs showed antibacterial activity against multidrug-resistant bacteria. ${ }^{93}$ Honary S. et al. studied the presence of amide and ester linkages in Penicillium citrinum, which are responsible for the formation of AgNPs. The presence of a fluorescence emission band at $414 \mathrm{~nm}$ showed that the AgNPs were bound with protein and the protein also present in its native form in solution. ${ }^{147}$ DLS study on the suspension of AgNPs was used to calculate the average particle size and particle distribution of the synthesized AgNPs. SEM, TEM and AFM were used to study the surface morphology, size and various shapes of AgNPs. ${ }^{36,109,116}$ Koyla H. et al. synthesized globular polycrystalline AgNPs using the leaf extract of spinach. ${ }^{108}$ Hamelian M. et al. synthesized plate- or rodshaped AgNPs using the plant extract of Thymus kotschyanus. ${ }^{116}$ Fig. 8 presents micrographs of the AgNPs synthesized by various methods under different optimization conditions. TGA was used to determine the effect of $\mathrm{AgNO}_{3}$ and L-cystine on the organic composition of the AgNPs. It was also used to determine the amount of organic material in the synthesized AgNPs and to predict their thermal stability.

\subsection{Factors affecting the microstructure and application of silver nanoparticles}

It has been reported that material properties are influenced by the structure (micro or nano) of the materials. ${ }^{182,183}$ The major physical and chemical parameters that affect the AgNP synthetic process are the temperature of the reaction, concentration of metal salt, content of extracts, $\mathrm{pH}$ of the reaction mixture, duration of the reaction and agitation. Parameters such as metal ion concentration, extract composition and reaction period have a major impact on the size, shape and morphology of AgNPs, where different experimental conditions lead to changes in the color of the reaction mixture. Yangqing He et al. reported that with an increase in the concentration of silver nitrate from 1 to $10 \mathrm{mM}$, the intensity of SPR peaks increased, which implies that at higher precursor salt concentration, more AgNPs were formed. A minor blue shift was observed for a higher concentration of $\mathrm{Ag}^{+}$ ions in the range of 425 to $418 \mathrm{~nm}$. FTIR analysis revealed the presence of flavonoids and proteins, which were responsible for the reduction and stabilization of the AgNPs. These nanoparticles showed cytotoxicity against human gastric carcinoma, acted as free radical scavengers and showed antimicrobial activity. ${ }^{92}$ AgNPs synthesized from grape and tomato showed good antioxidant antibacterial and protein kinase inhibitory activity. ${ }^{91}$ Most authors reported the suitability of basic medium for the synthesis of AgNPs due to the better stability of the synthesized NPs observed. ${ }^{89,92,98}$ Some other benefits reported under basic $\mathrm{pH}$ are fast growth rate, good yield and monodispersity, as well as enhanced reduction process. By altering the $\mathrm{pH}$, nearly spherical shaped AgNPs are converted into spherical AgNPs. The AgNPs formed in more basic $\mathrm{pH}(>11)$ and in acidic $\mathrm{pH}(<7)$ are unstable and agglomerate in the medium. Synthetic conditions such as 
stirring time and temperature are significant. Many researchers have used temperatures ranging from $20-100{ }^{\circ} \mathrm{C}$ to synthesize AgNPs from biopolymers and plant extracts; however, microorganisms die at high temperatures, and therefore they require a temperature of up to $40{ }^{\circ} \mathrm{C}$. The rate of synthesis of AgNPs increases with an increase in temperature $\left(30-90{ }^{\circ} \mathrm{C}\right.$ ) and encourages the production of small-size NPs. On average, the temperature range of $25-37{ }^{\circ} \mathrm{C}$ is considered suitable for the synthesis of AgNPs. Fig. 7 presents SEM images of AgNPs synthesized from different sources..$^{95,99,116}$ Several reports demonstrated that AgNPs absorb electromagnetic radiation in the visible range from 380 to $450 \mathrm{~nm}$, which is known as LSPR excitation. Honary S. et al. synthesized spherical monodispersed AgNPs with a size of $109 \mathrm{~nm}$ using Penicillium citrinum. PCS spectra show a polydispersity index (PDI) of 0.01 . For a broad size distribution of AgNPs, the PDI is greater than 0.7, and the PDI should be between 0.01 and 0.5 for good monodispersity of AgNPs. ${ }^{147}$ Based on the symmetry in the shape of AgNPs, many researchers reported with a decrease in symmetry, charge separation increases, and consequently the primary SPR peak shows a red shift, while due to the snipping of the corners of asymmetric AgNPs, a blue shift observed. In general for spherical AgNPs, they have more SPR peaks than irregular AgNPs. ${ }^{\mathbf{8 8 9 7}}$

\subsection{Indication for the formation of AgNPs}

The literature review has reported the appearance of colorless $\mathrm{AgNO}_{3}$ solution to yellow or brown-yellow solution as the indication that AgNPs have been synthesized. UV-vis data showed the maximum absorbance wavelength for the synthesized
AgNPs to be in the range of 400-460 nm. ${ }^{\mathbf{1 0 - 3 0}}$ The absorbance data also helps to analyze the effect of $\mathrm{pH}$, concentration of metal ions, and extract content on the size and stability of AgNPs. In most of the studies, SEM morphological analysis revealed spherical AgNPs, whereas few authors reported irregular, triangular, hexagonal, isotropic, polyhedral, flower, pentagonal, anisotropic and rod structures. ${ }^{37,40,88,91,92,149}$ Fig. 7 shows the SEM images of AgNPs with different shapes. The formation of face-centered cubic (FCC) crystalline-structured AgNPs has been reported by nearly all researchers using XRD studies. In some cases, AgNPs have been reported to show cubic and hexagonal structures also. EDAX is used to determine the elemental composition in nanomaterials. Depending on the reducing agent and other operating conditions, the stability of AgNPs may vary from 1 day to 1 year. Compared to plant extracts, the reaction mixture for the synthesis of AgNPs using microorganisms and bio-polymers is continually agitated to prevent agglomeration. The agitation of the reaction mixture achieved through the application of an external mechanical force can accelerate the formation of NPs.

\section{Applications of silver nanoparticles}

AgNPs have been used extensively as anti-bacterial agents in the health industry, food storage, textile coatings and a number of environmental applications. It is important to note that despite decades of use, the evidence for the toxicity of silver is still unclear. Products made with AgNPs have been approved by a variety of accredited bodies, including the US FDA, US EPA,

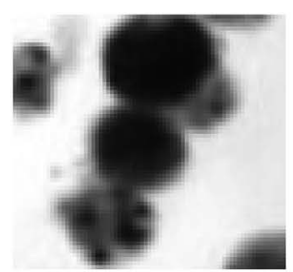

Polyhedral

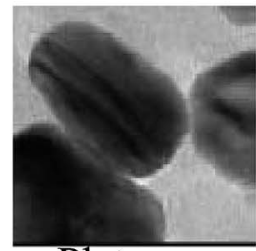

Plate

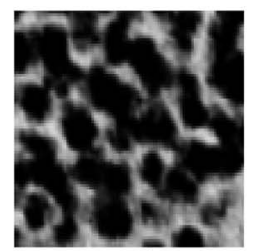

Isotropic
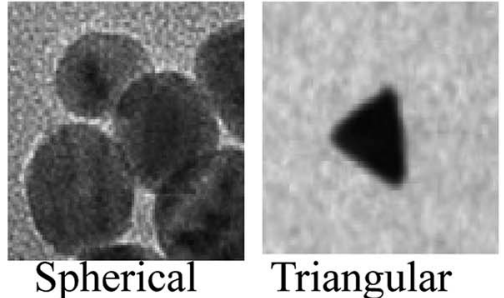

Triangular

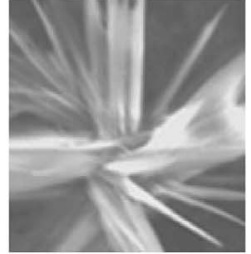

Flakes

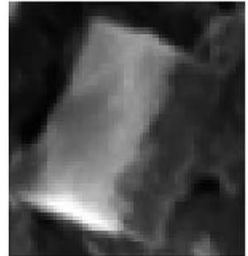

Cubical

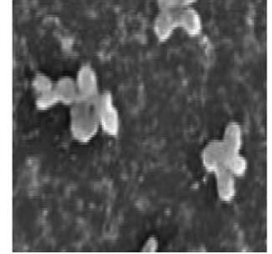

Flower

\section{Various Shapes of Silver Nanoparticles}

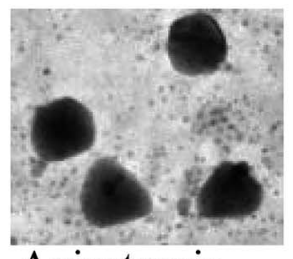

Anisotropic

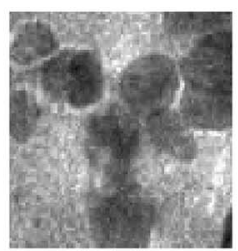

Variable

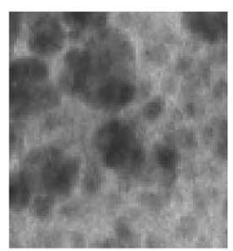

Irregular

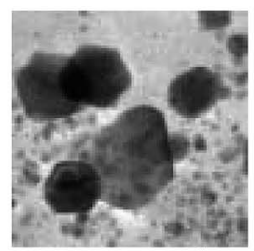

Hexagonal
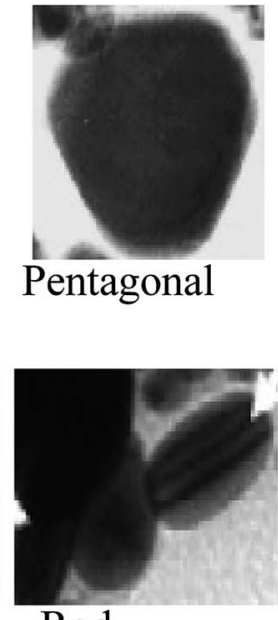

Rod

Fig. 7 SEM images of AgNPs synthesized from different sources. ${ }^{4}$ 

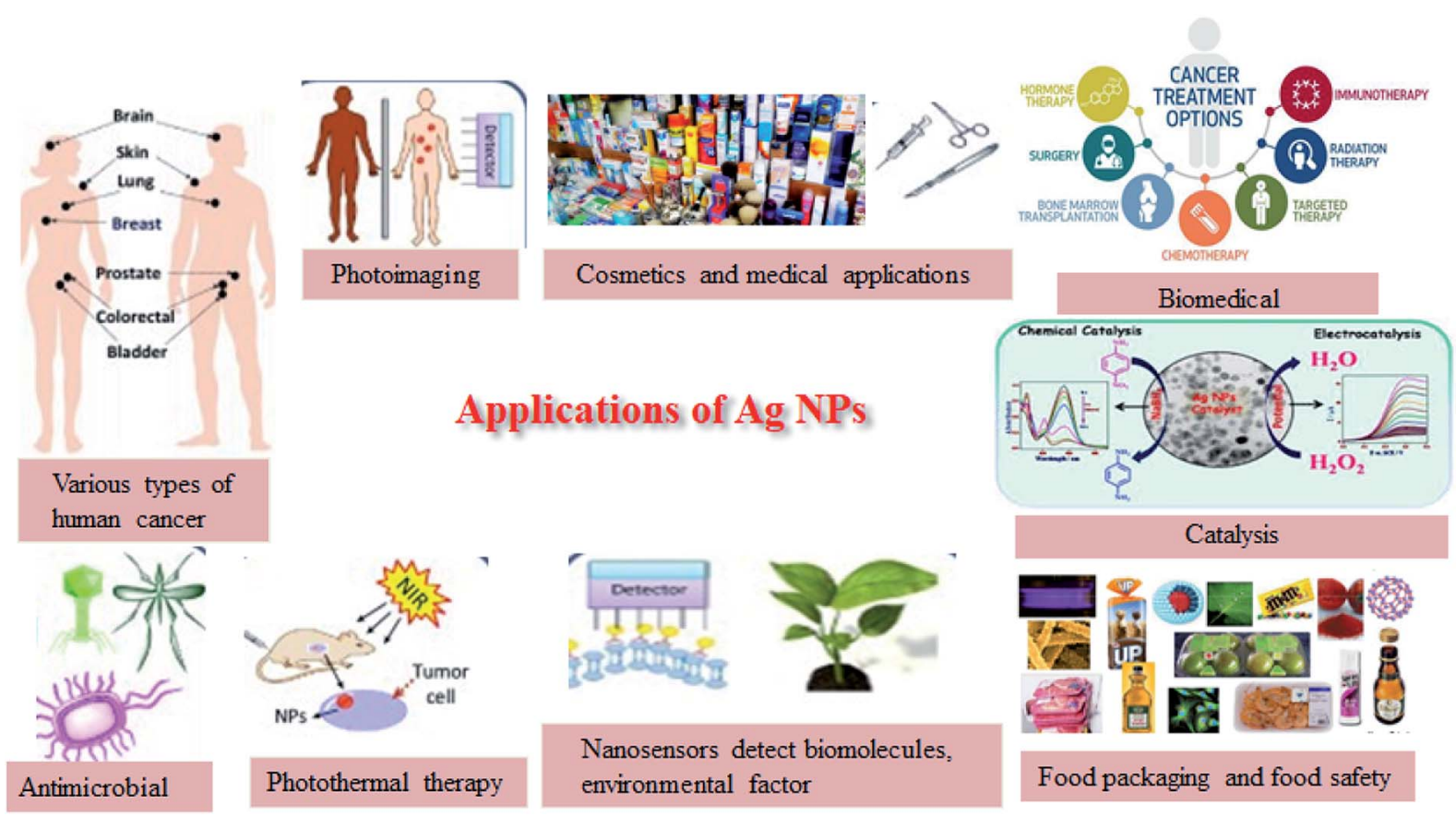

Fig. 8 Various applications of AgNPs.

and Japan SIAA, and in Korea. ${ }^{181}$ In addition, AgNPs are incorporated into nanoscale sensors due to their electrochemical properties, which can provide faster response times and lower detection limits. AgNPs are used as antibacterial agents, ranging from disinfecting medical devices and home appliances to water treatment. The textile industry has been encouraged to use AgNPs in various textile fabrics. Silver nanocomposite fibers with AgNPs incorporated into the fabric have been prepared in this direction. ${ }^{184}$ Cotton fibers with AgNPs are highly antibacterial against Escherichia coli. The catalytic activities of NPs differ from that of bulk materials, for example, high catalytic activity for the decoloration of monochrome black $\mathrm{T}$ dye in the presence of sodium borohydride (from $19.74 \%$ to $86.05 \%$ ) and a light source (from $41.96 \%$ to $80.11 \%){ }^{185}$ The optical properties of metallic NPs depend primarily on their surface plasmon resonance, where the plasmon refers to the collective oscillation of free electrons within the metallic NPs. ${ }^{193}$ The plasmon resonant peaks and line widths are well known to be sensitive to the size and shape of the NPs. AgNPs are used in agriculture to increase crop production, plant nutrition, and defend against diseases. ${ }^{189}$ The various applications of AgNPs are presented in Fig. 8.

Chen Yu et al. reported the application of AgNPs in catalysis, which enhanced the reduction rate of $\mathrm{NaBH}_{4}$ in the reduction of azo dye. ${ }^{65,186}$ Due to the enhanced electromagnetic field on the surface of AgNPs, AgNPs are broadly used in nanomedicine including diagnostics, biomedicines, nanoelectronics and molecular imaging. AgNPs act as nanoantennas due to the increase in their resonant SPR peak with an increase in the intensity of the electromagnetic field. AgNPs act as sensors with Raman spectroscopy to identify any molecule due specific vibrational modes. ${ }^{50,187}$ Due to the antimicrobial action of
AgNPs they are used in food packaging to prevent microbial infections. ${ }^{1{ }^{88,191}}$ AgNPs are used in nanosensors to analyze contaminations, colors or flavors, drinking water and for clinical diagnostics. ${ }^{189}$ AgNPs have found application in agriculture also. Plant productivity can be enhanced via the communication of nanotechnology-based smart plant sensors with actuate electronic device, where these sensors optimize and automate water and agrochemical allocation, and enable high-throughput plant chemical phenotyping. Ag NPs are used in plant nutrition and defense against diseases, ${ }^{192}$ where AgNPs can be delivered with pesticides to crops to enhance the production of crops in agriculture. ${ }^{190} \mathrm{AgNPs}$ are extensively used as therapeutic agents as antifungal, antimicrobial, anti-inflammatory and antiviral agents. Due to the antimicrobial action of AgNPs, they can be used in drug delivery to reduce the dose of drugs, improve specificity and decrease toxicity. ${ }^{88,193}$

\section{Conclusion}

In conclusion, considering environmental concerns for the synthesis of AgNPs, the green approach is preferred over conventional methodologies. The conventional synthetic methods for AgNPs require a huge amount of energy and hazardous chemicals (hydrazine or borohydride as reduction agents) and may lead to the formation of hazardous byproducts. The use of biodegradable polymers, sugars or polyphenols from plant extracts, enzymes and bacteria under ambient conditions may lead to the sustainable synthesis of AgNPs with a uniform size. AgNPs formed in more basic $\mathrm{pH}$ $(>11)$ are stable and in acidic $\mathrm{pH}(<7)$ are unstable and agglomerated. This implies that the size and stability of AgNPs are dependent on $\mathrm{pH}$. Using composites based on PEG and Ag 
CMC, Ag nanorods exhibiting luminescent properties, specific size and shape can be easily obtained using microwave irradiation. The synthesis of AgNPs is quite easy and simple using plants and their extract compared to other sources such as fungi and bacteria. The size and morphology of AgNPs varies with a variation in reaction parameters. The simple use of vitamins such as vitamin B2, B1, and C may produce NPs at ambient temperature in aqueous media. In addition, new biomimetic techniques have proven to be beneficial for the preparation of AgNPs, although there are still some inherent safety concerns. The green methods for the synthesis of AgNPs using biorenewable materials seems to be promising because they require non-toxic chemicals for the reduction of silver salt. This review provides a wide spectrum of all the natural resources such as plants, bacteria, fungi, and biopolymers for the production of AgNPs in the last ten years.

\section{Abbreviations}

AgNPs
NPS
PEG
SERS
DLS
TEM
SEM
XRD
EDAX
FTIR
CD
PAA
CMC
NTA
PCS
SPR
TGA

Silver nanoparticles

Nanoparticles

Polyethylene glycol

Surface-enhanced Raman scattering

Dynamic light scattering

Transmission electron microscopy

Scanning electron microscopy

$\mathrm{X}$-ray diffraction spectroscopy

Energy-dispersive X-ray spectroscopy

Fourier transform infrared spectroscopy

Cyclodextrin

Polyacrylic acid

Carboxy methyl cellulose

NP tracking analysis

Photon correlation spectroscopy

Surface plasmon resonance

Thermo-gravimetric analysis

\section{Conflicts of interest}

The authors do not have any conflict of interest.

\section{Acknowledgements}

The authors would like to acknowledge Department of Science and Technology (DST) and University fund for financial assistance.

\section{References}

1 R. P. Feynman, W. A. Goddard, D. Brenner, S. ELyshevski and G. F. Iafrate, in Handbook of Nanoscience, Engineering, and Technology, CRC Press, 3rd edn, 2012 Jun 12, pp. 26-35.

2 M. Rafique, I. Sadaf, M. S. Rafique and M. B. Tahir, A review on green synthesis of AgNPs and their applications, Artif. Cells, Nanomed., Biotechnol., 2017, 45(7), 1272-1291.
3 V. K. Sharma, R. A. Yngard and Y. Lin, AgNPs: green synthesis and their antimicrobial activities, Adv. Colloid Interface Sci., 2009, 145(1-2), 83-96.

4 S. K. Srikar, D. D. Giri, D. B. Pal, P. K. Mishra and S. N. Upadhyay, Green synthesis of AgNPs: a review, Green Sustainable Chem., 2016, 6(01), 34.

5 M. B. Galib, M. Mashru, C. Jagtap, B. J. Patgiri and P. K. Prajapati, Therapeutic potentials of metals in ancient India: A review through Charaka Samhita, J. Ayurveda Integr. Med., 2011, 2(2), 55, DOI: 10.4103/0975-9476.82523.

6 M. Rafique, I. Sadaf, M. S. Rafique and M. B. Tahir, A review on green synthesis of AgNPs and their applications, Artif. Cells, Nanomed., Biotechnol., 2017, 45(7), 1272-1291.

7 S. Naidu Krishna, P. Govender and J. K. Adam, Nano silver particles in biomedical and clinical applications, 2015.

$8 \mathrm{~N}$. Gokarneshan and K. Velumani, Application of nano silver particles on textile materials for improvement of antibacterial finishes, Global J. Pharm. Sci., 2017, 2, 1-4.

9 M. Carbone, D. T. Donia, G. Sabbatella and R. Antiochia, Silver NPs in polymeric matrices for fresh food packaging, J. King Saud Univ., Sci., 2016, 28(4), 273-279.

10 K. S. Naidu, P. Govender and J. K. Adam, Nano silver particles in biomedical and clinical applications, 2015.

11 X. Y. Dong, Z. W. Gao, K. F. Yang, W. Q. Zhang and L. W. Xu, Nanosilver as a new generation of silver catalysts in organic transformations for efficient synthesis of fine chemicals, Catal. Sci. Technol., 2015, 5(5), 2554-2574.

12 C. Caro, P. M. Castillo, R. Klippstein, D. Pozo and A. P. Zaderenko, Silver NPs: sensing and imaging applications, in SilverNPs, IntechOpen, 2010.

13 M. Balamurugan, S. Saravanan and T. Soga, Coating of green-synthesized silver NPs on cotton fabric, J. Coat. Technol. Res., 2017, 14(3), 735-745.

14 S. J. Oldenburg, Silver NPs: properties and applications, Sigma-Aldrich Co., 2014.

$15 \mathrm{H}$. Wei. Plasmonic silver NPs for energy and optoelectronic applications, Advances in Nanomaterials and nanostructures, 2011, vol. 229, pp. 171-184.

16 M. Qasim, N. Udomluck, J. Chang, H. Park and K. Kim, Antimicrobial activity of silver NPs encapsulated in poly$\mathrm{N}$-isopropylacrylamide-based polymeric NPs, Int. J. Nanomed., 2018, 13, 235.

$17 \mathrm{X}$. Yang, Y. Yu and Z. Gao, A highly sensitive plasmonic DNA assay based on triangular silver nanoprism etching, ACS Nano, 2014, 8(5), 4902-4907.

18 Z. Huang, Z. Li, R. Chen, G. Chen, D. Lin, G. Xi, Y. Chen, H. Lin and J. Lei, The application of silver nanoparticle based SERS in diagnosing thyroid tissue, in Journal of Physics: Conference Series, IOP Publishing, 2011, vol. 277(1), p. 012014.

19 J. Pulit-Prociak and M. Banach, Silver NPs-a material of the future...?, Open Chem., 2016, 14(1), 76-91.

$20 \mathrm{H}$. Zhang, Application of silver NPs in drinking water purification, 2013.

21 K. Chaloupka, Y. Malam and A. M. Seifalian, Nanosilver as a new generation of nanoproduct in biomedical applications, Trends Biotechnol., 2010, 28(11), 580-588. 
22 K. Park, D. Seo and J. Lee, Conductivity of silver paste prepared from NPs, Colloids Surf., A, 2008, 313, 351-354.

23 H. Wang, X. Qiao, J. Chen and S. Ding, Preparation of silver NPs by chemical reduction method, Colloids Surf., A, 2005, 256(2-3), 111-115.

24 P. Chen, L. Song, Y. Liu and Y. E. Fang, Synthesis of silver NPs by $\gamma$-ray irradiation in acetic water solution containing chitosan, Radiat. Phys. Chem., 2007, 76(7), 1165-1168.

25 M. Andersson, J. S. Pedersen and A. E. Palmqvist, Silver nanoparticle formation in microemulsions acting both as template and reducing agent, Langmuir, 2005, 21(24), 11387-11396.

26 R. A. Khaydarov, R. R. Khaydarov, O. Gapurova, Y. Estrin and T. Scheper, Electrochemical method for the synthesis of silver NPs, J. Nanopart. Res., 2009, 11(5), 1193-1200.

27 A. Pyatenko, K. Shimokawa, M. Yamaguchi, O. Nishimura and M. Suzuki, Synthesis of silver NPs by laser ablation in pure water, Appl. Phys. A: Mater. Sci. Process., 2004, 79(46), 803-806.

28 M. A. Valverde-Alva, T. García-Fernández, M. VillagránMuniz, C. Sánchez-Aké, R. Castañeda-Guzmán, E. Esparza-Alegría, C. F. Sánchez-Valdés, J. S. Llamazares and C. M. Herrera, Synthesis of silver NPs by laser ablation in ethanol: a pulsed photoacoustic study, Appl. Surf. Sci., 2015, 355, 341-349.

29 A. Jamaludin and C. K. Faizal, Autoclave-Assisted Synthesis of Silver NPs using MetroxylonSagu for Antibacterial Application, Indian J. Sci. Technol., 2017, 10, 6.

30 A. Pal, S. Shah and S. Devi, Microwave-assisted synthesis of silver NPs using ethanol as a reducing agent, Mater. Chem. Phys., 2009, 114(2-3), 530-532.

31 R. F. Elsupikhe, M. B. Ahmad, K. Shameli, N. A. Ibrahim and N. Zainuddin, Photochemical reduction as a green method for the synthesis and size control of silver NPs in к-carrageenan, IEEE Trans. Nanotechnol., 2016, 15(2), 209213.

32 H. H. Park, X. Zhang, Y. J. Choi, H. H. Park and R. H. Hill, Synthesis of Ag nanostructures by photochemical reduction using citrate-capped Pt seeds, J. Nanomater., 2011, 2011, 6.

33 S. Iravani, H. Korbekandi, S. V. Mirmohammadi and B. Zolfaghari, Synthesis of AgNPs: chemical, physical and biological methods, Res. Pharm. Sci., 2014, 9(6), 385.

34 M. Ghaffari-Moghaddam, R. Hadi-Dabanlou, M. Khajeh, M. Rakhshanipour and K. Shameli, Green synthesis of silver NPs using plant extracts, Korean J. Chem. Eng., 2014, 31(4), 548-557.

35 J. P. Yadav, S. Kumar, L. Budhwar, A. Yadav and M. Yadav, Characterization and antibacterial activity of synthesized silver and iron NPs using aloe vera, J. Nanomed. Nanotechnol., 2016, 7(3), 1000384.

36 B. Kumar, Y. Angulo, K. Smita, L. Cubal and A. Debut, Capuli cherry-mediated green synthesis of AgNPs under white solar and blue solar light, Particuology, 2015, 24, 123-128.

37 V. Dhand, L. Soumya, S. Bharadwaj, S. Chakra, D. Bhatt and B. Sreedhar, Green synthesis of AgNPs using Coffea arabica seed extract and its antibacterial activity, Mater. Sci. Eng. C, 2016, 58, 36-43.

38 R. Geethalakshmi and D. V. Sarada, Gold and AgNPs from Trianthemadecandra: synthesis, characterization, and antimicrobial properties, Int. J. Nanomed., 2012, 7, 5375.

39 V. K. Vidhu, S. A. Aromal and D. Philip, Green synthesis of AgNPs using Macrotylomauniflorum, Spectrochim. Acta, Part A, 2011, 83(1), 392-397.

40 S. P. Dubey, M. Lahtinen and M. Sillanpää, Tansy fruit mediated greener synthesis of silver and gold NPs, Process Biochem., 2010, 45(7), 1065-1071.

41 T. C. Leung, C. K. Wong and Y. Xie, Green synthesis of silver NPs using biopolymers, carboxymethylated-curdlan and fucoidan, Mater. Chem. Phys., 2010, 121(3), 402-405.

42 R. A. Futyra, K. M. Liskiewicz, V. Sebastian, S. Irusta, M. Arruebo, A. Kyziol and G. Stochel, Development of noncytotoxic silver-chitosan nanocomposites for efficient control of biofilm forming microbes, RSC Adv., 2017, 7, 52398, DOI: 10.1039/c7ra08359a.

43 N. T. Tho, T. N. An, M. D. Tri, T. V. Sreekanth, J. S. Lee, P. C. Nagajyothi and K. D. Lee, Green synthesis of silver nanoparticles using Nelumbo nucifera seed extract and its antibacterial activity, Acta Chim. Slov., 2013, 60(3), 673-678.

44 N. Kannan and S. Subbalaxmi, Green synthesis of silver NPs using Bacillus subtillus IA751 and its antimicrobial activity, Research Journal of Nanoscience and Nanotechnology, 2011, 1(2), 87-94.

45 O. V. Kharissova, H. V. R. Dias, B. I. Kharisov, B. O. Perez and V. M. J. Perez, The greener synthesis of NPs, Trends Biotechnol., 2013, 31(4), 240-248.

46 M. Ghaffari-Moghaddam, R. Hadi-Dabanlou, M. Khajeh, M. Rakhshanipour and K. Shameli, Green synthesis of silver NPs using plant extracts, Korean J. Chem. Eng., 2014, 31(4), 548-557.

47 M. Sastry, A. Ahmad, M. I. Khan and R. Kumar, Biosynthesis of metal nanoparticles using fungi and actinomycete, Curr. Sci., 2003, 85(2), 162-170; M. Sastry, A. Ahmad, M. I. Khan and R. Kumar, Microbial nanoparticle production, in Nanobiotechnology, 2003, vol. 85(2), pp. 163-169.

48 D. Nelson, D. M. Priscyla, L. A. Oswaldo, I. H. D. S. Gabriel and E. Elisa, Mechanical aspects of biosynthesis of silver nanoparticles by several Fusarium oxysporum strains, $J$. Nanobiotechnol., 2005, 3(1), 8-15.

49 B. Ankamwar, C. Damle, A. Ahmad and M. Sastry, Biosynthesis of gold and silver nanoparticles using Emblics Officinalis Fruit extract and their Phase Transfer and Transmetallation in an Organic Solution, J. Nanosci. Nanotechnol., 2005, 5(10), 1665-1671.

50 S. H. Lee and B. H. Jun, Silver Nanoparticles: Synthesis and application for nanomedicine, Int. J. Mol. Sci., 2019 Jan, $20(4), 865$.

51 S. Roy and T. K. Das, Plant mediated green synthesis of silver NPs - A review, International Journal of Plant Biology \& Research, 2015, 3(3), 1044-1055.

52 P. Logeswari, S. Silambarasan and J. Abraham, Synthesis of silver NPsusing plants extract and analysis of their 
antimicrobial property, J. Saudi Chem. Soc., 2015, 19, 311317.

53 S. Pirtarighat, M. Ghannadnia and S. Baghshahi, Green synthesis of silver NPs using the plant extract of Salvia spinosa grown in vitro and their antibacterial activity assessment, J. Nanostruct. Chem., 2019, 9(1), 1-9.

54 J. L. Gardea-Torresdey, E. Gomez, J. R. Peralta-Videa, J. G. Parsons, H. Troiani and M. Jose-Yacaman, Alfalfa sprouts: a natural source for the synthesis of silver NPs, Langmuir, 2003, 19(4), 1357-1361.

55 H. Bar, D. K. Bhui, G. P. Sahoo, P. Sarkar, S. P. De and A. Misra, Green synthesis of silver NPs using latex of Jatropha curcas, Colloids Surf., A, 2009, 339(1-3), 134-139.

56 R. Sithara, P. Selvakumar, C. Arun, S. Anandan and P. Sivashanmugam, Economical synthesis of silver nanoparticles using leaf extract of Acalypha hispida and its application in the detection of Mn (II) ions, J. $A d v$. Res., 2017, 8(6), 561-568.

57 A. J. Gavhane, P. Padmanabhan, S. P. Kamble and S. N. Jangle, Synthesis of silver NPs using extract of neem leaf and triphala and evaluation of their antimicrobial activities, Int. J. Pharma Bio Sci., 2012, 3(3), 88-100.

58 N. Ahmad and S. Sharma, Green synthesis of silver NPs using extracts of Ananascomosus, Green Sustainable Chem., 2012, 2(04), 141.

59 C. Ramteke, T. Chakrabarti, B. K. Sarangi and R. A. Pandey, Synthesis of silver NPs from the aqueous extract of leaves of Ocimum sanctum for enhanced antibacterial activity, $J$. Chem., 2012, 2013, 278925.

60 K. Roy, C. K. Sarkar and C. K. Ghosh, Green synthesis of silver NPs using fruit extract of Malus domestica and study of its antimicrobial activity, Digest Journal of Nanomaterials and Biostructures, 2014, 9(3), 1137-1147.

61 P. Velmurugan, S. Sivakumar, S. Young-Chae, J. Seong-Ho, Y. Pyoung-In and H. Sung-Chul, Synthesis and characterization comparison of peanut shell extract silver NPs with commercial silver NPs and their antifungal activity, J. Ind. Eng. Chem., 2015, 31, 51-54.

62 N. K. Sajeshkumar, P. J. Vazhacharickal, J. J. Mathew and A. Sebastin, Synthesis of silver NPs from curry leaf (Murrayakoenigii) extract and its antibacterial activity, CIBTech J. Pharm. Sci., 2015, 4, 15-25.

63 M. Firdaus, S. Andriana, W. Alwi, E. Swistoro, A. Ruyani and A. Sundaryono, Green synthesis of silver NPs using Carica Papaya fruit extract under sunlight irradiation and their colorimetric detection of mercury ions, in Journal of Physics: Conference Series, IOP Publishing, 2017, vol. 817(1), p. 012029.

64 J. S. Moodley, S. B. Krishna, K. Pillay and P. Govender, Green synthesis of silver NPs from Moringa oleifera leaf extracts and its antimicrobial potential, Adv. Nat. Sci.: Nanosci. Nanotechnol., 2018, 9(1), 015011.

65 C. Yu, J. Tang, X. Liu, X. Ren, M. Zhen and L. Wang, Green Biosynthesis of Silver NPs Using Eriobotrya japonica (Thunb.) Leaf Extract for Reductive Catalysis, Materials, 2019, 12(1), 189.
66 P. P. N. Vijaykumar, S. V. N. Pammi, P. Kollu, K. V. V. Satyanarayana and U. Shameem, Green Synthesis and Characterization of Silver NPs Using Boerhaaviadiffusa Plant Extract and Their Antibacterial Activity, Ind. Crops Prod., 2014, 52, 562-566, DOI: 10.1016/ j.indcrop.2013.10.050.

67 S. A. Anuj and K. B. Ishnava, Plant Mediated Synthesis of Silver NPs Using Dried Stem Powder of Tinosporacordifolia, Its Antibacterial Activity and Its Comparison with Antibiotics, Int. J. Pharm. Biol. Sci., 2013, 4, 849-863.

68 T. J. I. Edison and M. G. Sethuraman, Instant Green Synthesis of Silver NPs Using Terminalia chebula Fruit Extract and Evaluation of Their Catalytic Activity on Reduction of Methylene Blue, Process Biochem., 2012, 47, 1351-1357, DOI: 10.1016/j.procbio.2012.04.025.

69 S. P. Chandran, M. Chaudhary, R. Pasricha, A. Ahmad, M. Sastry, S. K. Srikar, et al., Synthesis of Gold Nanotriangles and Silver NPs Using Aloe vera Plant Extract, Biotechnol. Prog., 2006, 22, 577-583, DOI: 10.1021/ bp0501423.

70 R. S. Patil, M. R. Kokate and S. S. Kolekar, Bioinspired Synthesis of Highly Stabilized Silver NPs Using Ocimumtenuiflorum Leaf Extract and Their Antibacterial Activity, Spectrochim. Acta, Part A, 2012, 91, 234-238, DOI: 10.1016/j.saa.2012.02.009.

71 K. S. Mukunthan, E. K. Elumalai, E. N. Patel and V. R. Murty, Catharanthus roseus: A Natural Source for Synthesis of Silver NPs, Asian Pac. J. Trop. Biomed., 2011, 1, 270-274, DOI: 10.1016/S2221-1691(11)60041-5.

72 B. Ankamwar, C. Damle, A. Ahmad and M. Sastry, Biosynthesis of Gold and Silver NPs Using Emblica officinalis Fruit Extract, Their Phase Transfer and Transmetallation in an Organic Solution, J. Nanosci. Nanotechnol., 2005, 5, 1665-1671, DOI: 10.1166/ jnn.2005.184.

73 A. Tripathi, N. Chandrasekaran, A. M. Raichur and A. Mukherjee, Antibacterial Applications of Silver NPs Synthesized by Aqueous Extract of Azadirachtaindica (Neem) Leaves, J. Biomed. Nanotechnol., 2009, 5, 93-98, DOI: $10.1166 /$ jbn.2009.038.

74 V. K. Shukla, R. P. Singh and A. C. Pandey, Black Pepper Assisted Biomimetic Synthesis of Silver NPs, J. Alloys Compd., 2010, 507, L13-L16, DOI: 10.1016/ j.jallcom.2010.07.156.

75 S. M. Roopan, R. G. Madhumitha, A. A. Rahuman, C. Kamraj, A. Bharathi and T. V. Surendra, Low-Cost and Eco-Friendly Phyto-Synthesis of Silver NPs Using Coos nucifera Coir Extract and Its Larvicidal Activity, Ind. Crops Prod., 2013, 43, 631-635, DOI: 10.1016/ j.indcrop.2012.08.013.

76 M. Satishkumar, K. Sneha, S. W. Won, C. W. Cho, S. Kim and Y. S. Yun, Cinnamon zeylancium Bark Extract and Powder Mediated Green Synthesis of Nano-Crystalline Silver Particles and Its Antibacterial Activity, Colloids Surf., B, 2009, 73, 332-338, DOI: 10.1016/j.colsurfb.2009.06.005. 
77 N. K. Mondal, A. Chaudhury, P. Mukhopadhya, S. Chatterjee, K. Das and J. K. Datta, Green Synthesis of Silver NPs and Its Application for Mosquito Control, Asian Pac. J. Trop. Dis., 2014, 4, S204-S210, DOI: 10.1016/s22221808(14)60440-0.

78 P. Rao, M. S. Chandraprasad, Y. N. Lakshmi, J. Rao, P. Aishwarya and S. Shetty, Biosynthesis of Silver NPs Using Lemon Extract and Its Antibacterial Activity, International Journal of Multidisciplinary and Current Research, 2014, 2, 165-169.

79 E. K. Elumalai, K. Kayalvizhi and S. Silvan, Coconut Water Assisted Green Synthesis of Silver NPs, J. Pharm. BioAllied Sci., 2014, 6, 241-245, DOI: 10.4103/0975-7406.142953.

80 S. S. Shankar, A. Ahmad and M. Sastry, Geranium Leaf Assisted Biosynthesis of Silver NPs, Biotechnol. Prog., 2003, 19, 1627-1631, DOI: 10.1021/bp034070w.

81 C. Vishwasrao, B. Momin and L. Ananthanarayan, Green synthesis of silver nanoparticles using sapota fruit waste and evaluation of their antimicrobial activity, Waste Biomass Valorization, 2018, 1, DOI: 10.1007/s12649-0180230-0.

82 M. Shanmugavadivu, S. kuppusamy and R. Ranjithkumar, Synthesis of pomegranate peel extract mediated silver nano particles and its antibacterial activity, Am. J. Adv. Drug Delivery, 2014, 2(2), 174-182.

83 K. Paulkumar, G. Gnanajobitha, M. Vanaja, M. Pavunraj and G. Annadurai, Green synthesis of AgNPs and silver based chitosan bionanocomposite using stem extract of saccharum officinarum and assessment of its antibacterial activity, Adv. Nat. Sci.: Nanosci. Nanotechnol., 2017, 8, 9, DOI: 10.1088/2043-6254/aa7232.

84 P. Kouvaris, A. Delimitis, V. Zaspalis, D. Papadopoulos, A. S. Tsipas and N. Michailidis, Green synthesis and characterization of AgNPs produced using arbutus unedo leaf extract, Mater. Lett., 2012, 76, 18-20, DOI: 10.1016/ j.matlet.2012.02.025.

85 H. M. Nisha, R. Tamileswari, S. S. Jesurani, S. Kanagesan, M. Hashim and P. C. S. Alexander, Green synthesis of AgNPs from pomegranate leaves and analysis of antibacterial activity, International Journal of Advanced Technology in Engineering and Science, 2015, 3(6), 8.

86 S. Sarkar and V. Kotteeswaran, Green synthesis of AgNPs from aqueous leaf extract of pomegranate and their anticancer activity on human cervical cancer cells, Adv. Nat. Sci.: Nanosci. Nanotechnol., 2018, 9, 025014, DOI: 10.1088/2043-6254/aac590.

87 S. Mehnath, G. Sathishkumar, A. Arivoli, M. Rajan, R. A. Praphakar and M. Jeyaraj, Green synthesis of AgNPs by Walnut seed extract and its role in photocatalytic degradation of a textile dye effluent, Trans. Eng. Sci., 2017, 5(1), 31-40.

88 J. Huang, Q. Li, D. Sun, Y. Lu, Y. Su, X. Yang, H. Wang, Y. Wang, W. Shao, N. He, J. Hong and C. Chen, Biosynthesis of silver and gold NPs by novel sundried cinnamomumcamphora leaf, Nanotechnology, 2007, 18, 105104.
89 J. S. Joshi, S. J. Geetha, S. Al-Mamari and A. Al-Azkawi, Green synthesis of AgNPs using pomegranate peel extracts and its application in photocatalytic degradation of methylene blue, Jundishapur J. Nat. Pharm. Prod., 2018, 13(3), e67846, DOI: 10.5812/jjnpp.67846.

90 S. Ahmed, Saifullah, M. Ahmad, B. L. Swami and S. Ikram, Greensynthesis ofAgNPs using azadirachtaindicaaquous leaf extract, J. Radiat. Res. Appl. Sci., 2015, 9, 1-7.

91 K. Roy, S. Biswas and P. C. Banerjee, Green synthesis of silver nano particles by using Grape (Vitis vinifera) fruit extract: Characterization of the particles and study of antibacterial activity, Res. J. Pharm., Biol. Chem. Sci., 2014, 4(1), 1271.

92 Y. He, F. Wei, Z. Ma, H. Zhang, Q. Yang, B. Yao, Z. Huang, J. Li, C. Zeng and Q. Zang, Green synthesis of AgNPs using seed extract of Alpiniakatsumadai, and their antioxidant, cytotoxicity, and antibacterial activities, $R S C A d v$., 2017, 7, 39842-39851.

93 Z. A. Ali, R. Yahya, S. D. Sekaran and R. Puteh, Green synthesis of AgNPs using apple extract and its antibacterial properties, Adv. Mater. Sci. Eng., 2016, 4102196.

94 M. Behravan, A. H. Panahi, A. Naghizadeh, M. Ziaee, R. Mahdavi and A. Mirzapour, Facile green synthesis of AgNPs using Berberis Vulgaris leaf and root aqueous exract and its antibacterial acticity, Int. J. Biol. Macromol., 2019, 124, 148-154.

95 M. Sathishkumar, K. Sneha, S. W. Won, C. W. Cho, S. Kim and Y. S. Yun, Cinnamon zeylanicum bark extract and powder mediated green synthesis of nano-crystalline silver particles and its bactericidal activity, Colloids Surf., B, 2009, 73(2), 332-338.

96 A. Sudha, J. Jeyakanthan and P. Srinivasan, Green synthesis of AgNPs using lippianodiflora aerial extract and evaluation of their antioxidant, antibacterial and cytotoxic effects, Resour.-Effic. Technol., 2017, 3, 506-515.

97 B. Kumar, K. Smita, L. Cumbal and A. Debut, Green synthesis of AgNPs using Andean blackberry fruit extract, Saudi J. Biol. Sci., 2015, 24, 45-50.

98 D. R. G. Caroling, S. K. Tiwari, D. R. A. M. Ranjitham and R. Suja, Biosynthesis of AgNPsusimg aqueous Broccoli extract-characterization and study of antimicrobial, cytotoxic effects, Asian Journal of Pharmaceuticals and Clinical Research, 2013, 6(4), 164-172.

99 N. I. Azkiya, M. Masruri and S. M. Ulfa, Green synthesis of AgNPs using extract of pinusmerkusiijungh\& De vriese cone flower, IOP Conf. Ser.: Mater. Sci. Eng., 2018, 299, 012070.

100 M. Sathishkumar, K. Sneha and Y. S. Yun, Immobilization of silver NPs synthesized using Curcuma longa tuber powder and extract on cotton cloth for bactericidal activity, Bioresour. Technol., 2010, 101(20), 7958-7965.

101 G. Von White, P. Kerscher, R. M. Brown, J. D. Morella, W. McAllister, D. Dean and C. L. Kitchens, Green synthesis of robust, biocompatible AgNPs using garlic extract, J. Nanomater., 2012, 2012, 55. 
102 G. H. Priyaa and K. B. Satyan, Biological synthesis of AgNPs using ginger (Zingiberofficinale) extract, J. Environ. Nanotechnol., 2014, 3(4), 32-40.

103 S. V. Otari, R. M. Patil, S. J. Ghosh and S. H. Pawar, Green phytosynthesis of silver NPs using aqueous extract of Manilkarazapota (L.) seeds and its inhibitory action against Candida species, Mater. Lett., 2014, 116, 367-369.

104 S. P. Vinay, N. Chandrashekar and C. P. Chandrappa, AgNPs: Synthesized by leaves extract of Avocado and their antibacterial activity, International Journal of Engineering Development and Research, 2017, 5(2), 1608-1613.

105 M. Shaik, M. Khan, M. Kuniyil, A. Al-Warthan, H. Alkhathlan, M. Siddiqui, J. Shaik, A. Ahamed, A. Mahmood, M. Khan and S. Adil, Plant-extract-assisted green synthesis of AgNPs using Origanum vulgare L. Extract and their microbicidal activities, Sustainability, 2018, 10(4), 913.

106 P. Joshi and P. Vyas, Green synthesis of AgNPs using root extract of Croton sparsilflorus and their antimicrobial activity, Int. J. Sci. Res., 2016, 5(12), 3791.

107 C. Baskaran and V. Ratha bai, Green Synthesis of AgNPs using Coleus forskohlii roots extract and its antimicrobial activity against Bacteria and Fungus, Int. J. Drug Dev. Res., 2013, 5(1), 114-119.

108 H. Kolya, P. Maiti, A. Pandey and T. Tripathy, Green synthesis of AgNPs with antimicrobial and azo dye (Congo red) degradation properties using Amaranthus gangeticus Linn leaf extract, J. Anal. Sci. Technol., 2015, 6(1), 33.

109 P. S. Vankar and D. Shukla, Biosynthesis of AgNPs using lemon leaves extract and its application for antimicrobial finish on fabric, Appl. Nanosci., 2012, 2(2), 163-168.

110 H. M. Ibrahim, Green synthesis and characterization of AgNPs using banana peel extract and their antimicrobial activity against representative microorganisms, J. Radiat. Res. Appl. Sci., 2015, 8(3), 265-275.

111 F. Mares-Briones, M. S. Aguilar, N. Fletes, S. E. BorjasGarcia and G. Rosas, Green Synthesis of AgNPs Using Valeriana officinalis Aqueous Extract, Microsc. Microanal., 2018, 24(S1), 1728-1729.

112 A. Rautela, J. Rani and M. D. Das, Green synthesis of AgNPs from Tectonagrandis seeds extract: characterization and mechanism of antimicrobial action on different microorganisms, J. Anal. Sci. Technol., 2019, 10(1), 5.

113 N. Ahmad and S. Sharma, Green synthesis of AgNPs using extracts of Ananascomosus, Green Sustainable Chem., 2012, 2(04), 141.

114 G. Bagherzade, M. M. Tavakoli and M. H. Namaei, Green synthesis of AgNPs using aqueous extract of saffron (Crocus sativus L.) wastages and its antibacterial activity against six bacteria, Asian Pac. J. Trop. Biomed., 2017, 7(3), 227-233.

115 A. Saxena, R. M. Tripathi and R. P. Singh, Biological synthesis of AgNPs by using onion (Allium cepa) extract and their antibacterial activity, Digest Journal of Nanomaterials and Biostructures, 2010, 5(2), 427-432.
116 M. Hamelian, M. M. Zangeneh, A. Amisama, K. Varmira and H. Veisi, Green synthesis of AgNPs using Thymus kotschyanus extract and evaluation of their antioxidant, antibacterial and cytotoxic effects, Appl. Organomet. Chem., 2018, 32(9), e4458.

117 M. Umadevi, S. Shalini and M. R. Bindhu, Synthesis of silver nanoparticle using D. carota extract, Adv. Nat. Sci.: Nanosci. Nanotechnol., 2012, 3(2), 025008.

118 P. Karthiga, Preparation of AgNPs by Garcinia mangostana stem extract and investigation of the antimicrobial properties, Biotechnology Research and Innovation, 2018, 2(1), 30-36.

119 M. M. Khalil, E. H. Ismail, K. Z. El-Baghdady and D. Mohamed, Green synthesis of AgNPs using olive leaf extract and its antibacterial activity, Arabian J. Chem., 2014, 7(6), 1131-1139.

120 L. M. Carrillo-López, H. A. Zavaleta-Mancera, A. VilchisNestor, R. M. Soto-Hernández, J. Arenas-Alatorre, L. I. Trejo-Téllez and F. Gómez-Merino, Biosynthesis of AgNPs using Chenopodium ambrosioides, J. Nanomater., 2014, 2014, 198.

121 R. Ghosh, S. Dutta and S. Bhattacharyya, Green Synthesis of Silver Nanoparticle by Acalyphaindica and its Antifungal Effect against Phytopathogen Colletotrichum capsici, Acta Scientific Agriculture, 2018, 2(5), 27-31.

122 A. Saxena, R. M. Tripathi, F. Zafar and P. Singh, Green synthesis of AgNPs using aqueous solution of Ficusbenghalensis leaf extract and characterization of their antibacterial activity, Mater. Lett., 2012, 67(1), 91-94.

123 U. Murad, S. A. Khan, M. Ibrar, S. Ullah and U. Khattak, Synthesis of silver and gold NPs from leaf of Litchi chinensis and its biological activities, Asian Pac. J. Trop. Biomed., 2018, 8(3), 142.

124 M. Baghayeri, B. Mahdavi, Z. Hosseinpor-Mohsen Abadi and S. Farhadi, Green synthesis of silver nanoparticles using water extract of Salvia leriifolia: Antibacterial studies and applications as catalysts in the electrochemical detection of nitrite, Appl. Organomet. Chem., 2018 Feb, 32(2), e4057.

125 V. Sreelakshmy, M. K. Deepa and P. Mridula, Green synthesis of AgNPs from Glycyrrhiza glabra root extract for the treatment of gastric ulcer, J. Dev. Drugs, 2016, 5(152), 2.

126 M. S. Alsalhi, S. Devanesan, A. A. Alfuraydi, R. Vishnubalaji, M. A. Munusamy, K. Murugan, M. Nicoletti and G. Benelli, Green synthesis of AgNPs using Pimpinella anisum seeds: antimicrobial activity and cytotoxicity on human neonatal skin stromal cells and colon cancer cells, Int. J. Nanomed., 2016, 11, 4439.

127 Y. Huo, P. Singh, Y. J. Kim, V. Soshnikova, J. Kang, J. Markus, S. Ahn, V. Castro-Aceituno, R. Mathiyalagan, M. Chokkalingam and K. S. Bae, Biological synthesis of gold and silver chloride NPs by Glycyrrhiza uralensis and in vitro applications, Artif. Cells, Nanomed., Biotechnol., 2018, 46(2), 303-312.

128 C. H. De Barros, G. C. Cruz, W. Mayrink and L. Tasic, Biobased synthesis of silver NPs from orange waste: effects 
of distinct biomolecule coatings on size, morphology, and antimicrobial activity, Nanotechnol., Sci. Appl., 2018, 11, 1.

129 M. Shanmugavadivu and S. Kuppusamy, Green synthesis of AgNPs using Citrus reticulata fruit peel aqueous extract and their antibacterial activity, Int. J. Adv. Res., 2017, 5(4), 700708.

130 M. Rafique, I. Sadaf, M. S. Rafique and M. B. Tahir, A review on green synthesis of AgNPs and their applications, Artif. Cells, Nanomed., Biotechnol., 2017, 45(7), 1272-1291.

131 R. M. Slawson, J. T. Trevors and H. Lee, Silver accumulation and resistance in Pseudomonas stutzeri, Arch. Microbiol., 1992, 158, 398-404.

132 F. D. Pooley, Bacteria accumulate silver during leaching of sulphide ore minerals, Nature, 1982, 296, 642-643.

133 T. Klaus, R. Joerger, E. Olsson and C.-G. Granqvist, Silverbased crystalline NPs, microbially fabricated, Proc. Natl. Acad. Sci. U. S. A., 1999, 96, 13611-13614.

134 K. Kalimuthu, R. S. Babu, D. Venkataraman, M. Bilal and S. Gurunathan, Biosynthesis of silver nanocrystals by Bacillus licheniformis, Colloids Surf., B, 2008, 65(1), 150153.

135 A. Nanda and M. Saravanan, Biosynthesis of silver NPs from Staphylococcus aureus and its antimicrobial activity against MRSA and MRSE, Nanomedicine, 2009, 5(4), 452456.

136 S. Shivaji, S. Madhu and S. Singh, Extracellular synthesis of antibacterial silver NPs using psychrophilic bacteria, Process Biochem., 2011, 46(9), 1800-1807.

137 T. Monowar, M. Rahman, S. Bhore, G. Raju and K. Sathasivam, Silver NPs Synthesized by Using the EndophyticBacteriumPantoeaananatis are Promising Antimicrobial Agents against Multidrug Resistant Bacteria, Molecules, 2018, 23(12), 3220.

138 N. Samadi, D. Golkaran, A. Eslamifar, H. Jamalifar, M. R. Fazeli and F. A. Mohseni, Intra/extracellular biosynthesis of silver NPs by an autochthonous strain of proteus mirabilis isolated fromphotographic waste, $J$. Biomed. Nanotechnol., 2009, 5(3), 247-253.

139 N. Mokhtari, S. Daneshpajouh, S. Seyedbagheri, R. Atashdehghan, K. Abdi, S. Sarkar, S. Minaian, H. R. Shahverdi and A. R. Shahverdi, Biological synthesis of very small silver NPs by culture supernatant of Klebsiella pneumonia: The effects of visible-light irradiation and the liquid mixing process, Mater. Res. Bull., 2009, 44(6), 1415-1421.

140 S. Y. Lee, Plastic bacteria? Progress and prospects for polyhydroxyalkanoate production in bacteria, Trends Biotechnol., 1996, 14(11), 431-438; T. E. Shehata and A. G. Marr, Effect of nutrient concentration on the growth of Escherichia coli, J. Bacteriol., 1971, 107(1), 210-216.

141 A. R. Shahverdi, S. Minaeian, H. R. Shahverdi, H. Jamalifar and A. A. Nohi, Rapid synthesis of silver NPs using culture supernatants of Enterobacteria: a novel biological approach, Process Biochem., 2007, 42(5), 919-923.

142 O. V. Kharissova, H. R. Dias, B. I. Kharisov, B. O. Pérez and V. M. Pérez, The greener synthesis of NPs, Trends Biotechnol., 2013, 31(4), 240-248.
143 C. Saravanan, R. Rajesh, T. Kaviarasan, K. Muthukumar, D. Kavitake and P. H. Shetty, Synthesis of AgNPs using bacterial exopolysaccharide and its application for degradation of azo-dyes, Biotechnology Reports, 2015, 15, 33-40.

144 G. S. Dhillon, S. K. Brar, S. Kaur and M. Verma, Green approach for nanoparticle biosynthesis by fungi: current trends and applications, Crit. Rev. Biotechnol., 2012, 32(1), 49-73.

145 K. S. Siddiqi and A. Husen, Fabrication of metal NPs from fungi and metal salts: scope and application, Nanoscale Res. Lett., 2016, 11(1), 98.

146 B. Xue, D. He, S. Gao, D. Wang, K. Yokoyama and L. Wang, Biosynthesis of silver NPs by the fungus Arthrodermafulvum and its antifungal activity against genera of Candida, Aspergillus and Fusarium, Int. J. Nanomed., 2016, 11, 1899.

147 S. Honary, H. Barabadi, E. Gharaei-Fathabad and F. Naghibi, Green synthesis of silver NPs induced by the fungus Penicillium citrinum, Trop. J. Pharm. Res., 2013, 12(1), 7-11.

148 P. Mukherjee, M. Roy, B. P. Mandal, G. K. Dey, P. K. Mukherjee, J. Ghatak, A. K. Tyagi and S. P. Kale, Green synthesis of highly stabilized nanocrystalline silver particles by a non-pathogenic and agriculturally important fungus T. asperellum, Nanotechnology, 2008, 19(7), 075103.

149 V. C. Verma, R. N. Kharwar and A. C. Gange, Biosynthesis of antimicrobial silver NPs by the endophytic fungus Aspergillus clavatus, Nanomedicine, 2010, 5(1), 33-40.

150 G. Li, D. He, Y. Qian, B. Guan, S. Gao, Y. Cui, K. Yokoyama and L. Wang, Fungus-mediated green synthesis of silver NPs using Aspergillus terreus, Int. J. Mol. Sci., 2012, 13(1), 466-476.

151 G. Subashini and S. Bhuvaneswari, NPs from Fungi (MycoNPs);Fungi and their role in sustainable Development:current perspectives, 2018, pp. 753-779.

152 S. S. Birla, S. C. Gaikwad, A. K. Gade and M. K. Rai, Rapid synthesis of silver NPs from Fusarium oxysporum by optimizing physicocultural conditions, Sci. World J., 2013, 1-12.

153 S. Neethu, S. J. Midhun, E. K. Radhakrishnan and M. Jyothis, Green synthesized silver NPs by marine endophytic fungus Penicillium polonicum and its antibacterial efficacy against biofilm forming, multidrugresistant Acinetobacter baumanii, Microb. Pathog., 2018, 116, 263-272.

154 M. N. Khan, T. A. Khan, Z. Khan and S. A. Al-thabaiti, Green synthesis of biogenic silver nanomaterials using Raphanus sativus extract, effects of stabilizers on the morphology, and their antimicrobial activities, Bioprocess Biosyst. Eng., 2015 1, 38(12), 2397-2416.

155 L. Ma, W. Su, J. X. Liu, X. X. Zeng, Z. Huang, W. Li, Z. C. Liu and J. X. Tang, Optimization for extracellular biosynthesis of silver NPs by Penicillium aculeatum Su1 and their antimicrobial activity and cytotoxic effect compared with silver ions, Mater. Sci. Eng., C, 2017, 1(77), 963-971. 
156 R. Al-Bahrani, J. Raman, H. Lakshmanan, A. A. Hassan and V. Sabaratnam, Green synthesis of silver NPs using tree oyster mushroom Pleurotusostreatus and its inhibitory activity against pathogenic bacteria, Mater. Lett., 2017, 186, 21-25.

157 M. Jalal, M. Ansari, M. Alzohairy, S. Ali, H. Khan, A. Almatroudi and K. Raees, Biosynthesis of Silver NPs from Oropharyngeal Candida glabrata Isolates and Their Antimicrobial Activity against Clinical Strains of Bacteria and Fungi, Nanomaterials, 2018, 8(8), 586.

158 M. Eugenio, N. Müller, S. Frasés, R. Almeida-Paes, L. M. Lima, L. Lemgruber, M. Farina, W. de Souza and C. Sant'Anna, Yeast-derived biosynthesis of silver/silver chloride NPs and their antiproliferative activity against bacteria, RSC Adv., 2016, 6(12), 9893-9904.

159 S. V. Otari, R. M. Patil, N. H. Nadaf, S. J. Ghosh and S. H. Pawar, Green synthesis of silver NPs by microorganism using organic pollutant: its antimicrobial and catalytic application, Environ. Sci. Pollut. Res., 2014, 21(2), 1503-1513.

160 K. Ishida, T. F. Cipriano, G. M. Rocha, G. Weissmüller, F. Gomes, K. Miranda and S. Rozental, Silver nanoparticle production by the fungus Fusarium oxysporum: nanoparticle characterisation and analysis of antifungal activity against pathogenic yeasts, Mem. Inst. Oswaldo Cruz, 2014, 109(2), 220-228.

161 A. Deljou and S. Goudarzi, Green syntyhesis of the AgNPs using Thermophilic Bacillus Sp.AZ1 and its antimicrobial activity against several human pathogenetic bacteria, Iran. J. Biotechnol., 2016, 14(2), e1259.

162 G. Sagar and B. Ashok, Green synthesis of AgNPs using Aspergillus niger and its efficacy against human pathogens, Eur. J. Exp. Biol., 2012, 2, 1654-1658.

163 A. M. Elgorban, A. N. Al-Rahman, S. R. Sayed, A. Hirad, A. A.-F. Mostafa and A. H. Bahkali, Antimicrobial activity and green synthesis of AgNPs using Trochodermaviride, Biotechnol. Biotechnol. Equip., 2016, 30(2), 299-304.

164 T. C. Leung, C. K. Wong and Y. Xie, Green synthesis of silver NPs using biopolymers, carboxymethylated-curdlan and fucoidan, Mater. Chem. Phys., 2010, 121(3), 402-405.

165 A. Regiel-Futyra, M. Kus-Liśkiewicz, V. Sebastian, S. Irusta, M. Arruebo, A. Kyzioł and G. Stochel, Development of noncytotoxic silver-chitosan nanocomposites for efficient control of biofilm forming microbes, RSC Adv., 2017, $7(83), 52398413$.

166 D. Kadam, B. Momin and S. S. L. ShanoobaPalamthodi, Physiochemical and functional properties of chitosan based nano composite films incorporated with biogenic silver NPs, Carbohydr. Polym., 2019, 211, 124-132.

167 M. B. Ahmad, M. Y. Tay, K. Shameli, M. Z. Hussein and J. J. Lim, Green synthesis and characterization of silver/ chitosan/polyethylene glycol nanocomposites without any reducing agent, Int. J. Mol. Sci., 2011, 12(8), 4872-4884.

168 P. Vasileva, B. Donkova, I. Karadjova and C. Dushkin, Synthesis of starch-stabilized silver NPs and their application as a surface plasmon resonance-based sensor of hydrogen peroxide, Colloids Surf., A, 2011, 382(1-3), 203-210.

169 A. Atta, H. Al-Lohedan and A. Ezzat, Synthesis of silver NPs by green method stabilized to synthetic human stomach fluid, Molecules, 2014, 19(5), 6737-6753.

170 Q. Wu, H. Cao, Q. Luan, J. Zhang, Z. Wang, J. H. Warner and A. AR Watt, Biomolecule-assisted synthesis of watersoluble silver NPs and their biomedical applications, Inorg. Chem., 2008, 47(13), 5882-5888.

$171 \mathrm{~S}$. Si and T. K. Mandal, Tryptophanbased peptides to synthesize gold and silver NPs: A mechanistic and kinetic study, Chem. - Eur. J., 2007, 13(11), 3160-3168.

172 A. Mantion, A. G. Guex, A. Foelske, L. Mirolo, K. M. Fromm, M. Painsi and A. Taubert, Silver nanoparticle engineering via oligovalineorganogels, Soft Matter, 2008, 4(3), 606-617.

173 J. Kasthuri, S. Veerapandian and N. Rajendiran, Biological synthesis of silver and gold NPs using apiin as reducing agent, Colloids Surf., B, 2009, 68(1), 55-60.

174 M. Safaepour, A. R. Shahverdi, H. R. Shahverdi, M. R. Khorramizadeh and A. R. Gohari, Green synthesis of small silver nanoparticles using geraniol and its cytotoxicity against fibrosarcoma-wehi 164, Avicenna J. Med. Biotechnol., 2009, 1(2), 111.

175 A. Hebeish, A. El-Shafei, S. Sharaf and S. Zaghloul, Novel precursors for green synthesis and application of silver nanoparticles in the realm of cotton finishing, Carbohydr. Polym., 2011, 84(1), 605-613.

176 D. Maity, M. Kanti Bain, B. Bhowmick, J. Sarkar, S. Saha, K. Acharya, M. Chakraborty and D. Chattopadhyay, In situ synthesis, characterization, and antimicrobial activity of silver nanoparticles using water soluble polymer, J. Appl. Polym. Sci., 2011, 122(4), 2189-2196.

177 I. Medina-Ramirez, S. Bashir, Z. Luo and J. L. Liu, Green synthesis and characterization of polymer-stabilized silver nanoparticles, Colloids Surf., B, 2009, 73(2), 185-191.

178 S. H. Lee and B. H. Jun, Silver Nanoparticles: Synthesis and application for nanomedicine, Int. J. Mol. Sci., 2019, 20(4), 865.

179 R. Das, S. S. Nath, D. Chakdar, G. Gope and R. Bhattacharjee, Preparation of silver nanoparticles and their characterization, J. Nanotechnol., 2009, 5, 1-6.

180 S. S. Nath and D. G. Gope, Synthesis of CdS and ZnS quantum dots and their applications in Electronics, NanoTrends, 2007, 2, 20-28.

181 S. Link and M. A. Ei-Sayed, Optical properties and ultrafast dynamics of metallic nanocrystals, Annu. Rev. Phys. Chem., 2003, 54, 331-366.

182 W. Wei, J. Wu, S. Cui, Y. Zhao, W. Chen and L. Mi, $\alpha-\mathrm{Ni}$ (OH) 2/NiS 1.97 heterojunction composites with excellent ion and electron transport properties for advanced supercapacitors, Nanoscale, 2019, 11(13), 6243-6253.

183 W. Wei, S. Cui, L. Ding, L. Mi, W. Chen and X. Hu, Urchinlike Ni1/3Co2/3 (CO3) 1/2 $(\mathrm{OH})^{*} 0.11 \mathrm{H} 2 \mathrm{O}$ for ultrahigh-rate electrochemical supercapacitors: structural evolution from solid to hollow, ACS Appl. Mater. Interfaces, 2017, 9(46), 40655-40670. 
184 D. Hebbalalu, J. Lalley, M. N. Nadagouda and R. S. Varma, Greener techniques for the synthesis of AgNPs using plant extracts, enzymes, bacteria, biodegradable polymers, and microwaves, ACS Sustainable Chem. Eng., 2013, 1(7), 703712.

185 El-NourKM, A. A. Eftaiha, A. Al-Warthan and R. A. Ammar, Synthesis and applications of silver nanoparticles, Arabian J. Chem., 2010, 3(3), 135-140.

186 A. Singhal, N. Singhal, A. Bhattacharya and A. Gupta, Synthesis of silver nanoparticles (AgNPs) using Ficus retusa leaf extract for potential application as antibacterial and dye decolourising agents, Inorg. NanoMet. Chem., 2017, 47(11), 1520-1529.

187 K. M. El-Nour, A. A. Eftaiha, A. Al-Warthan and R. A. Ammar, Synthesis and applications of silver nanoparticles, Arabian J. Chem., 2010, 3(3), 135-140.

188 A. A. Sorescu and M. R. Ion, Green synthesis of AgNPs using plant extracts, Science Conference, 2016, 4(1), p. 386.
189 A. Vogt, F. Rancan, S. Ahlberg, B. Nazemi, C. S. Choe, M. E. Darvin, S. Hadam, U. Blume-Peytavi, K. Loza, J. Diendorf and M. Epple, Interaction of dermatologically relevant NPs with skin cells and skin, Beilstein J. Nanotechnol., 2014, 5(1), 2363-2373.

190 M. Kah, N. Tufenkji and J. C. White, Nano-enabled strategies to enhance crop nutrition and protection, Nat. Nanotechnol., 2019 Jun, 14(6), 532.

191 M. M. Berekaa, Nanotechnology in food industry; advances in food processing, packaging and food safety, Int. J. Curr. Microbiol. Appl. Sci., 2015, 4(5), 345-357.

192 M. Kah, N. Tufenkji and J. C. White, Nano-enabled strategies to enhance crop nutrition and protection, Nat. Nanotechnol., 2019 Jun, 14(6), 532.

193 L. A. Austin, M. A. Mackey, E. C. Dreaden and M. A. ElSayed, The optical, photothermal, and facile surface chemical properties of gold and silver nanoparticles in biodiagnostics, therapy, and drug delivery, Arch. Toxicol., 2014, 88(7), 1391-1417. 